\title{
Groundwater-Stream Connectivity
} Mediates Metal(loid) Geochemistry in the Hyporheic Zone of Streams Impacted by Historic Mining and Acid Rock Drainage

\author{
Beth Hoagland $^{1 *}$, Alexis Navarre-Sitchler ${ }^{1}$, Rory Cowie ${ }^{2}$ and Kamini Singha ${ }^{1}$ \\ 'Department of Geology and Geological Engineering, Colorado School of Mines, Golden, CO, United States, ${ }^{2}$ Alpine Water \\ Resources, Limited Liability Company (LLC), Silverton, CO, United States
}

\section{OPEN ACCESS}

Edited by:

Dipankar Dwivedi

Lawrence Berkeley National Laboratory, United States

Reviewed by:

Alessandra Marzadri, University of Trento, Italy

Alberto Bellin,

University of Trento, Italy

*Correspondence:

Beth Hoagland

hoagland@mines.edu

Specialty section: This article was submitted to Water and Critical Zone, a section of the journal

Frontiers in Water

Received: 29 August 2020 Accepted: 29 October 2020 Published: 11 December 2020

Citation:

Hoagland B, Navarre-Sitchler A,

Cowie $R$ and Singha K (2020)

Groundwater-Stream Connectivity Mediates Metal(loid) Geochemistry in

the Hyporheic Zone of Streams Impacted by Historic Mining and Acid

Rock Drainage.

Front. Water 2:600409.

doi: 10.3389/frwa.2020.600409
High concentrations of trace metal(loid)s exported from abandoned mine wastes and acid rock drainage pose a risk to the health of aquatic ecosystems. To determine if and when the hyporheic zone mediates metal(loid) export, we investigated the relationship between streamflow, groundwater-stream connectivity, and subsurface metal(loid) concentrations in two $\sim 1-\mathrm{km}$ stream reaches within the Bonita Peak Mining District, a US Environmental Protection Agency Superfund site located near Silverton, Colorado, USA. The hyporheic zones of reaches in two streams-Mineral Creek and Cement Creek-were characterized using a combination of salt-tracer injection tests, transient-storage modeling, and geochemical sampling of the shallow streambed $(<0.7 \mathrm{~m})$. Based on these data, we present two conceptual models for subsurface metal(loid) behavior in the hyporheic zones, including (1) well-connected systems characterized by strong hyporheic mixing of infiltrating stream water and upwelling groundwater and (2) poorly connected systems delineated by physical barriers that limit hyporheic mixing. The comparatively large hyporheic zone and high hydraulic conductivities of Mineral Creek created a connected stream-groundwater system, where mixing of oxygen-rich stream water and metal-rich groundwater facilitated the precipitation of metal colloids in the shallow subsurface. In Cement Creek, the precipitation of iron oxides at depth $(\sim 0.4 \mathrm{~m})$ created a low-hydraulic-conductivity barrier between surface water and groundwater. Cemented iron oxides were an important regulator of metal(loid) concentrations in this poorly connected stream-groundwater system due to the formation of strong redox gradients induced by a relatively small hyporheic zone and high fluid residence times. A comparison of conceptual models to stream concentration-discharge relationships exhibited a clear link between geochemical processes occurring within the hyporheic zone of the well-connected system and export of particulate $\mathrm{Al}, \mathrm{Cu}, \mathrm{Fe}$, and $\mathrm{Mn}$, while the poorly connected system did not have a 
notable influence on metal concentration-discharge trends. Mineral Creek is an example of a hyporheic system that serves as a natural dissolved metal(loid) sink, whereas poorly connected systems such as Cement Creek may require a combination of subsurface remediation of sediments and mitigation of upstream, iron-rich mine drainages to reduce metal export.

Keywords: hyporheic zone, metal(loid)s, acid rock drainage (ARD), concentration-discharge (C-Q) relationships, tracer test experiments, Bonita Peak Mining District

\section{INTRODUCTION}

Over 64,000 inactive metal mines persist in the United States and contribute high metal loads to streams and groundwater, damaging aquatic ecosystems (Nordstrom, 2011; HudsonEdwards, 2016; Horton and San Juan, 2020). In watersheds impacted by historic mining activity, chemical weathering of minerals containing high metal content can occur at rates three times as fast as natural weathering rates (Alpers et al., 2007). Some of these metal(loid)s, such as arsenic (As), copper $(\mathrm{Cu})$, and manganese $(\mathrm{Mn})$, are commonly found in high concentrations downstream of hard-rock mines. They pose a well-documented risk to human and aquatic health (Smedley and Kinniburgh, 2002), and their toxicity and concentration are highly sensitive to changes in $\mathrm{pH}$ and redox conditions of streams and groundwater (Smedley and Kinniburgh, 2002; Borch et al., 2010). Mixing of oxic stream water and sub-oxic, shallow groundwater within the hyporheic zone can rapidly change the geochemical conditions of the shallow subsurface over space and time (e.g., Bencala, 2011; Boano et al., 2014). Unlike the fate of organic carbon or nutrients, which are the focus of many hyporheic studies to date, the behavior of metal(loid)s in mine-impacted hyporheic zones are complicated by reactions with sediments, such as sorption/desorption (Harvey and Fuller, 1998), storage via complexation with organic matter (Findlay et al., 2003), surface redox chemistry, or (co)precipitation/dissolution reactions. Furthermore, redox gradients that form as a result of fluid exchange across the groundwater-surface water boundary (Kasahara and Hill, 2007) are often facilitated by diverse microbial metabolisms and can control the fate and form of nutrients (Findlay et al., 2003; Fischer et al., 2005). However, the role of groundwater-surface water connectivity in mediating the toxicity and mobility of redox-sensitive metal(loid)s is not well-quantified and could have important implications for our estimates of metal fluxes from mine-impacted watersheds (Gandy et al., 2007).

Hydrological parameters such as permeability, transient storage zone area, fluid exchange rate, and residence time influence hyporheic zone characteristics (e.g., Miller et al., 2006; Boano et al., 2014). These parameters vary seasonally as a function of changing temperature (Weber et al., 2010), discharge (Wondzell, 2006), and microbial processes (Saup et al., 2019). Seasonal changes in stream discharge and subsurface saturation may, in turn, affect the kinetics of metal(loid) release from the hyporheic zone, given that abiotic and biotic process rates are hypothesized to be inherently different in areas characterized by variable fluid saturation and redox chemistry compared to permanently oxic or anoxic environments (Borch et al., 2010). In an abandoned mine system, for example, the delivery of As via groundwater and the residence time of As in the hyporheic zone were greater in the summer and led to the saturation of sediment sorption sites and a resulting decrease in As storage (Brown et al., 2007). Similarly, seasonal fluctuations in discharge and groundwater levels in marine and estuarine environments influenced the speciation of metal(loid)s via interactions with sediments such as sorption, complexation, and precipitation (Howard et al., 1995; Fattorini et al., 2008). These previous studies suggest an important link between streamflow, hyporheic area and mass transfer rates, and metal(loid) redox chemistry.

In addition to the influence of streamflow on the physical and geochemical conditions of the hyporheic zone, previous studies have highlighted that streambed characteristics and mixing conditions within the hyporheic zone regulate microbial community composition (e.g., Feris et al., 2004; Danczak et al., 2016; Nelson et al., 2019) and trace metal concentrations (e.g., Benner et al., 1995; Harvey and Fuller, 1998; Nagorski and Moore, 1999; Gandy et al., 2007). Systems such as the East River near Crested Butte, CO, USA, where highly permeable, graveldominated streambed sediments control groundwater-stream mixing, were characterized by high levels of dissolved oxygen at depth, microbial homogenization, and seasonal variability in metal concentrations in the shallow subsurface (Nelson et al., 2019; Saup et al., 2019). Furthermore, increased mixing depth and supply of dissolved organic carbon caused respiration of Mn-oxides in the East River during spring snowmelt, whereas a small and well-oxygenated hyporheic zone caused Mn-oxide accumulation during baseflow conditions (Bryant et al., 2020). In contrast, the Colorado River near Rifle, CO, USA, had fine sediments and a low influx of surface water into the hyporheic zone, which reduced mixing, promoted redox stratification, and created a unique hyporheic microbiome (Danczak et al., 2016; Nelson et al., 2019). Given the potential influence of hyporheic zone connectivity on microbial processes and sediment-water interactions, we hypothesized that the degree of groundwatersurface water connection will influence whether the hyporheic zone serves as a source or sink of trace metal(loid)s.

The behavior of solutes in the hyporheic zone can be reflected at the reach or catchment scale in how solute concentrations respond to changes in streamflow, also known as concentration-discharge (CQ) relationships, yet few studies directly link hyporheic processes to stream export of major ions (Hoagland et al., 2017; Singley et al., 2017) and even fewer 
investigate hyporheic influences on trace metal export. Specific to trace metals, Sherrell and Ross (1999) linked metal(loid)-Q relationships to changing flow-path contributions to the stream, where anthropogenic sources of metals were accessed at high flow and in-stream processes aided metal removal at low flow. In other catchments, a link between metal concentrations and stream discharge was difficult to identify (Nagorski et al., 2003), or metal-discharge relationships were attributed to the formation of inorganic colloids (Trostle et al., 2016). These previous studies suggest that in-stream chemical dynamics, including processes occurring in the hyporheic zone, may mediate the response of trace metal(loid)s to stream discharge and overall metal(loid) export from disturbed watersheds.

The headwaters of the Animas River in southwestern Colorado are an ideal location to study the relationship between stream-groundwater connectivity, metal(loid) export, and stream discharge. This site is home to $\sim 1,500$ abandoned gold and silver mines (Buxton et al., 1997) and the site of the Bonita Peak Mining District, a US Environmental Protection Agency (EPA) Superfund site (Figure 1). The primary purpose of the Superfund site is to investigate the potential impacts of contaminated soil, groundwater, and surface waters on aquatic and human health. Bedrock weathering and abandoned mine adits contribute diffuse subsurface and surface flows of metalladen waters to the Animas River headwaters and have led to the development of several water sources with elevated metal concentrations (Guerard et al., 2004). The headwaters of the Animas River gained publicity in August 2015 when an accidental breach of a tunnel connected to the legacy Gold King Mine led to the release of $\sim 11$ million liters of acidic mine drainage into surface waters that persisted as far as San Juan River in New Mexico ( $\sim 200 \mathrm{~km}$ downstream) (Rodriguez-Freire et al., 2016). Dissolved metals associated with the Gold King Mine spill were hypothesized to have rapidly immobilized in the headwaters via adsorption onto streambed sediments and precipitation of Fe-oxyhydroxide minerals (Rodriguez-Freire et al., 2016; Saup et al., 2017). Although the Gold King Mine spill contributed a slug of metals to the system over a short period of time, numerous historic mines or mining-related sources contribute diffuse loads upwards of 20.4 million liters per day to the Animas River headwaters (USEPA, 2016). Furthermore, the three streams that comprise the headwaters-Cement Creek, Mineral Creek, and the Upper Animas River-exhibit wide seasonal variations in streamflow and $\mathrm{pH}$. For example, $\mathrm{pH}$ and discharge $(Q)$ measurements in 2019 at the US Geological Survey monitoring stations (sites 09358550 and 09359019) ranged from winter lows of $\mathrm{pH} \sim 3.5$ and $Q \sim 0.3 \mathrm{~m}^{3} \mathrm{~s}^{-1}$ to summer highs of $\mathrm{pH} \sim 6.4$ and $Q \sim 14.8 \mathrm{~m}^{3} \mathrm{~s}^{-1}$ in Cement Creek, whereas $\mathrm{pH}$ ranged from winter lows of $\mathrm{pH} 4.8$ and $Q \sim 0.4 \mathrm{~m}^{3} \mathrm{~s}^{-1}$ to summer highs of $\mathrm{pH}$ 7.4 and $Q \sim 33.7 \mathrm{~m}^{3} \mathrm{~s}^{-1}$ in Mineral Creek (USGS, 2020).

The goal of this study was to understand how streamhyporheic-groundwater connectivity influences dissolved metal(loid) concentrations and mobilization in streams impacted by mining activities. To address this goal, we investigated two reaches in the Bonita Peak Mining District downstream of redox-sensitive metal(loid) sources: (a) Cement Creek, a low-pH system with extensive ferricrete formation, located downstream of the Gold King Mine, and (b) Mineral Creek, a circumneutral $\mathrm{pH}$ stream without ferricrete precipitates, located downstream of the Koehler Tunnel (Figure 1C). At both sites, we conducted salt-tracer injection tests at high and at low flow, collected seasonal water samples, and compiled historical sediment and water data to constrain the timing of metal(loid) release or storage in the hyporheic zone.

\section{METHODS}

\section{Hydrogeologic Setting and Site Selection}

The headwaters of the Animas River, located in the San Juan Mountains of southwestern Colorado, USA, are characterized by a complex geologic and mining history. The three tributaries that comprise the headwaters-Cement Creek, Mineral Creek, and the Upper Animas River-connect south of Silverton, Colorado, to form the Animas River (Figure 1B), which serves as a primary drinking and agricultural water source for communities in southwestern Colorado, northern New Mexico, and southeastern Utah. The tributaries and town of Silverton lie almost completely within the Silverton caldera and are underlain by highly mineralized and faulted terrain that formed as a result of volcanotectonic and hydrothermal alteration events that occurred from 35 to $10 \mathrm{Ma}$ (Yager and Bove, 2007). Metalrich sulfide minerals formed during the mid- to late-Tertiary supported a gold and silver mining industry in this region beginning in the late 1800's and lasting for over a century (Yager and Bove, 2007). The history of mining in combination with natural sulfide weathering has led to low-pH and Fe-rich groundwater and streams in the Animas River headwaters (e.g., Guerard et al., 2004).

Given the complex terrain and geology of the Animas headwater catchments, careful consideration was taken when choosing stream reaches of interest. Based on historical data collected by the US Geological Survey and the Animas River Stakeholders Group, we identified a $\sim 1.2-\mathrm{km}$ stream reach in Mineral Creek and a $\sim 1.8$-km stream reach in Cement Creek located downstream of trace metal sources (Figure 1C). Mine drainage with elevated concentrations of metal(loid)s, such as arsenic, aluminum, copper, manganese, and zinc, discharges from Koehler Tunnel at the headwaters of Mineral Creek and from the Henrietta, Joe and John, and Lark Mines into the headwaters of Prospect Gulch, which eventually drains into Cement Creek (Figure 1C). Other major contributors of metals to Cement Creek include the Natalie/Occidental Mine, the American Tunnel, the Red and Bonita Mine, and the Mogul Mine (Figure 1C), all of which are mines prioritized by the EPA Superfund site. In addition to their location downstream of mine drainages, we selected reaches with the same stream gradient $(\sim 0.03 \mathrm{~km} / \mathrm{km})$ to control for potential effects of stream gradient on hyporheic exchange flows (e.g., Hester and Doyle, 2008) and with similar drainage areas (24.6 and $23.1 \mathrm{~km}^{2}$ for Cement Creek and Mineral Creek reaches, respectively). Furthermore, the topographical divide Mineral Creek and Cement Creek constitutes the southern lobe of the Red Mountain acid-sulfate alteration system, which contains silver, lead, and copper mined from breccia-pipe chimney deposits (Bove et al., 2007). Both sites 
A

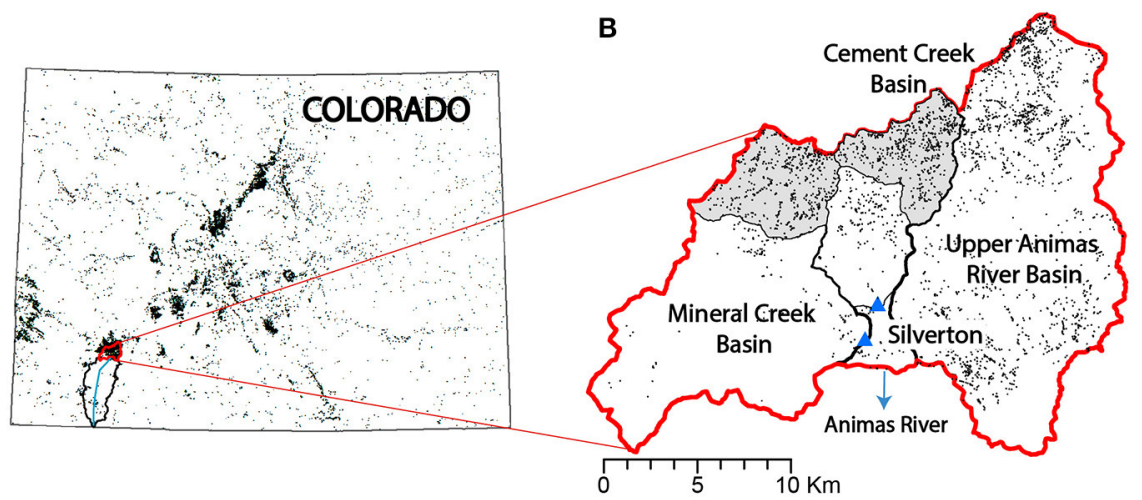

Upper Mineral Creek

C

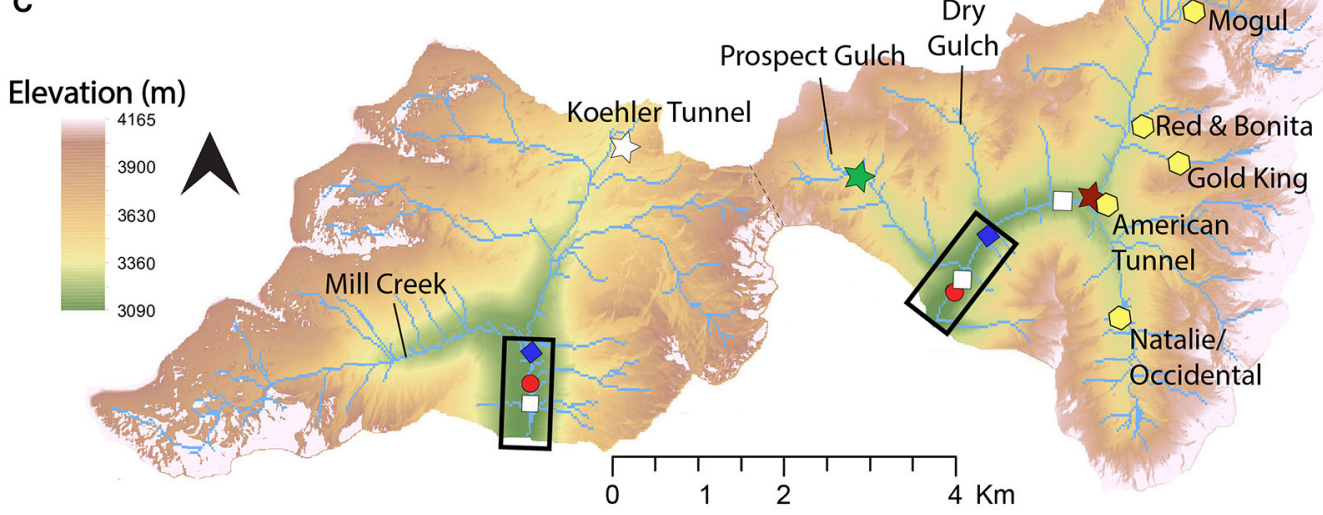

D

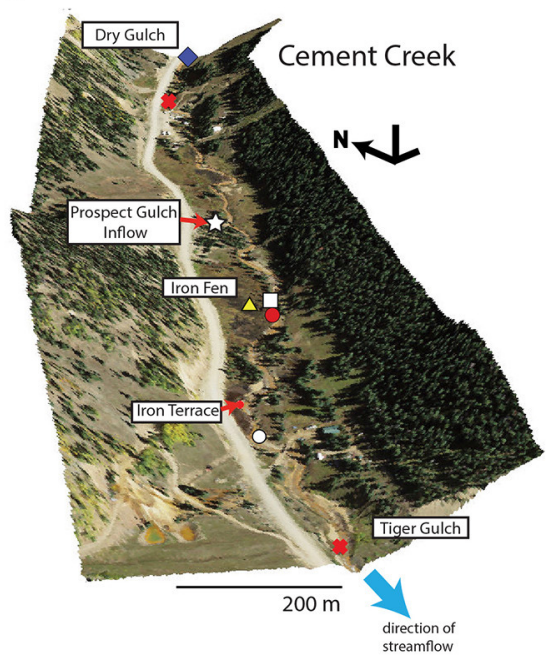

E

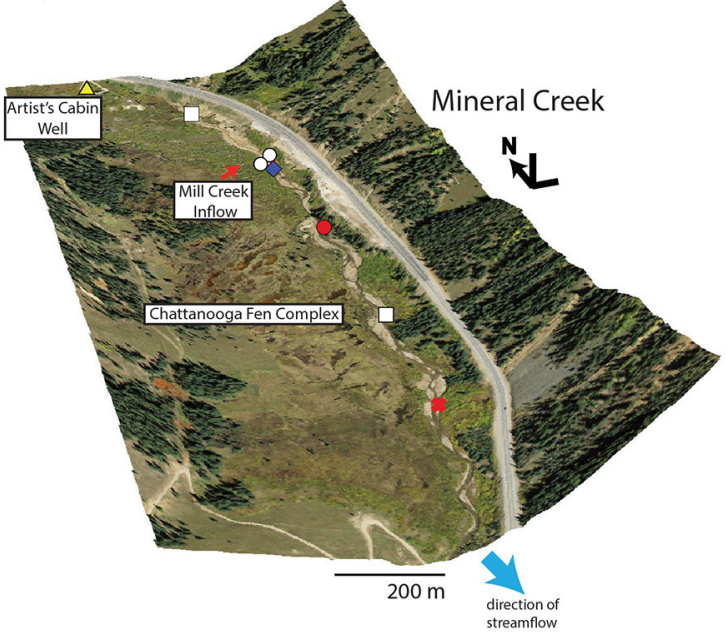

\begin{tabular}{|l|l|}
\hline & Legend \\
Joe and John, Henrietta, and Lark Mines & Gladstone Treatment Plant \\
Tracer Injection Point & Koehler Tunnel, Longfellow and Junction Mines \\
Stilling Wells & $\Delta$ USGS Stream Gages \\
Hyporheic Zone Well Clusters & $\triangle$ Groundwater well \\
Conductivity Logger & \\
Additional stream water sampling locations & \\
\hline
\end{tabular}

FIGURE 1 | The upper Mineral Creek and Cement Creek study areas are located at (A) the headwaters of the Animas River watershed in (B) the Bonita Peak Mining District north of Silverton, in the San Juan Mountains of southwestern Colorado. The study areas and the locations of the redox-sensitive metal sources are 
FIGURE 1 | highlighted in (C) and denoted in (B) by the gray-shaded regions within the greater Cement Creek and Mineral Creek basins. Black points on subplots $(\mathbf{A}, \mathbf{B})$ represent all mine-related features in the state of Colorado and the Animas River headwaters (Horton and San Juan, 2020). The tracer study reaches are outlined by black boxes and are located downstream of trace metal(loid) sources at the headwaters of Mineral Creek and the headwater of the Prospect Gulch tributary. The blue triangles in (B,D) represent stream gages managed by the US Geological Survey at Cement Creek (Gage \#09358550) and Mineral Creek (Gage \#09359010). The white circles in (D,E) represent additional stream water sampling sites. Detailed views of the tracer test reaches [as outlined by the black boxes in (C)] are highlighted for (D) Cement Creek at Prospect Gulch and (E) Mineral Creek at Chattanooga Fen and presented at a 65 viewing angle. Elevation above mean sea level is mapped for (C) using the Shuttle Radar Topography Mission 30-m digital elevation model. Aerial imagery for (D,E) is from the USDA National Agriculture Imagery Program dated September 20, 2017.

contain iron-rich groundwater wetlands, or iron fens (Chimner et al., 2010), along the banks.

The Mineral Creek stream reach is located within the 0.07$\mathrm{km}^{2}$ Chattanooga fen complex (Figure 1E) and will be referred to as the "MC-Fen" site throughout the remainder of the text. The MC-Fen is a rare and sensitive ecosystem characterized by low $\mathrm{pH}(\sim 3.4)$, high dissolved Fe concentrations, and unique vegetation including Sphagnum mosses, Carex sedges, and bog birch (Chimner et al., 2010). By definition, fens are groundwaterfed wetlands, and the iron fens in the Silverton area predate mining activity by thousands of years (Chimner et al., 2010). The water table in the fen is shallow, fluctuating between 0 and $40 \mathrm{~cm}$ below ground level (bgl) (Chimner et al., 2010). The MCFen is located $\sim 2.8 \mathrm{~km}$ downstream of the first trace metal(loid) source, which includes two draining abandoned mines, Koehler Tunnel and Junction Mine, and one abandoned dry mine, Longfellow Mine (Figure 1). Prior to remediation efforts in the early 2000's, flows from the Koehler Tunnel constituted nearly $50 \%$ of flow entering the head of the stream and contained elevated concentrations of copper, lead, zinc, and arsenic (Runkel and Kimball, 2002; Walton-Day et al., 2007; Runkel et al., 2009b). In 2003, a bulkhead was installed in the Koehler Tunnel, reducing surface drainage from 11.7 to $<0.3 \mathrm{~L} / \mathrm{s}$ (Runkel et al., 2009a). Although these efforts significantly reduced metal loads, the Koehler Tunnel and Junction Mine and the Longfellow Mine have been identified by the Bonita Peak Mining District Superfund as primary sources of mining-related contamination to the watershed, where waste rock samples exceeded the human health risk-based level for arsenic (Smith, 2018).

The second trace metal(loid) source includes several abandoned mines, including the Henrietta Mine, Joe and John Mine, and Lark Mine, located at the head of the Prospect Gulch tributary, which flows into Cement Creek. The Gladstone Treatment Plant, managed by the US EPA and located at the upstream end of the Cement Creek study reach, treats discharge from the Gold King Mine adit with lime $(\mathrm{CaO})$ to raise the $\mathrm{pH}$ and trigger the precipitation of metals out of solution. However, the $\mathrm{pH}$ downstream of the plant at the outlet of Cement Creek remains low $(\sim 3<\mathrm{pH}<\sim 4.5)$, which is likely a result of several other draining mines such as the Mogul Mine or Red and Bonita Mine (Figure 1C) that contribute low $\mathrm{pH}$ and metal-rich water to Cement Creek and do not undergo treatment (USGS, 2020). Historic data show dissolved aluminum, copper, and zinc concentrations as high as $\sim 18,500,285$, and $7,280 \mu \mathrm{g} / \mathrm{L}$, respectively, in Cement Creek downstream of the Prospect Gulch inflow (Johnson et al., 2007). Recently, the Bonita Peak Mining District Superfund identified the Henrietta Mine as a priority contamination source as a result of elevated aqueous concentrations of $\mathrm{Al}, \mathrm{Cd}, \mathrm{Cu}, \mathrm{Pb}$, and $\mathrm{Zn}$ and high sediment-As concentrations (USEPA, 2017). We investigated Cement Creek along a reach extending from the Gladstone Treatment Plant to $\sim 600 \mathrm{~m}$ downstream of Prospect Gulch (referred to throughout the remainder of the text as CC-PG; Figure 1D). Metal-rich groundwater in the Cement Creek catchment can discharge into the stream along this reach via several flow paths, including direct discharge from upslope mine drainages, natural seeps and springs, or diffuse subsurface discharge through iron fens and streambanks. Furthermore, the mine drainages can comprise a notable portion of total streamflow in Cement Creek during baseflow conditions (Cowie and Roberts, 2020). Cement Creek, including within the study area, is characterized by abundant ferricrete deposits along the stream channel and banks. Ferricrete deposits form when reducing acidic groundwater, containing high concentrations of iron, interacts with the atmosphere or oxygenated surface water and causes the precipitation of amorphous iron oxyhydroxides that, in turn, cement clastic sedimentary conglomerates (Guerard et al., 2004; Walton-Day et al., 2007). These ferricrete deposits serve as a long-term sink of metals and contain solid-phase concentrations as high as $\sim 300$ ppm As, 350 ppm Cu, and 350 ppm Pb (Wirt et al., 2007).

\section{Field Instrumentation}

Stream gages were installed at MC-Fen on May 20, 2019 and CC-PG on July 18, 2019 (Figures 1D,E). Water and barometric pressure were measured every $15 \mathrm{~min}$ at each gage using pressure transducers (HOBO U20) and corrected to water level with a staff plate. A rating curve was built for each site based on 12 flow measurements at Cement Creek and 11 flow measurements at Mineral Creek using a $\mathrm{HACH}$ flow meter (Supplementary Figure 1). The rating curve at Mineral Creek was supplemented with eight additional measurements collected from a nearby stream gage managed by the US Forest Service (Mineral Creek below Mill Creek; Figure 1E). Given the spatial variability in alpine rainfall events, we include data from a NOAH-II All-Weather Precipitation Gauge (ETI Instrument Systems) installed by the US EPA and managed by the Mountain Studies Institute. ${ }^{1}$ Discharge measurements were compared to 10 -min precipitation measurements from the Gladstone Treatment Plant weather station (Figure 1C). Water levels were summed for daily measurements following corrections for evaporative losses. Snow water equivalent data were obtained

\footnotetext{
${ }^{1}$ www.mountainstudies.org
} 
from the Snowpack Telemetry Network (SNOTEL) monitoring site (\#629) located downstream of MC-Fen (USDA, 2020).

A cluster of three hyporheic zone monitoring wells was installed in the streambed at each site to determine vertical hydraulic gradients, perform slug tests, and sample porewater chemistry (Figures 1D,E; described in "Section continuous salttracer injection tests"). The wells were installed on July 18, 2019 in CC-PG and May 21, 2019 in MC-Fen and constructed from PVC with a $19-\mathrm{mm}$ inner diameter and a $0.2-\mathrm{mm}$ slotted screen comprising the bottom $10 \mathrm{~cm}$ of each well. The hyporheic zone monitoring wells at Cement Creek $(37.88049,-107.66814)$ extended to depths of 28, 44, and $58 \mathrm{~cm}$ (Figure 1D), and the wells at Mineral Creek (37.86970, -107.72387) extended to depths of 20, 40, and $68 \mathrm{~cm}$ (Figure 1E). To determine the vertical hydraulic gradient, manual water level measurements were made with a water level tape in each well prior to the high and low flow tracer tests at each site (described below). Slug tests were performed in the monitoring wells, and hydraulic conductivity was estimated according to Bouwer and Rice (1976).

To compare temporal variations in average linear velocities for CC-PG and MC-Fen, thermal probes were installed adjacent to the well clusters in each stream reach. The Thermochron temperature logging iButtons (Model \#DS 1922L-F5) recorded stream-water temperature and streambed temperatures at 10and $40-\mathrm{cm}$ depths every $15 \mathrm{~min}$ with a precision of $0.0625^{\circ} \mathrm{C}$. Our primary focus of these measurements was twofold: (a) explore the effects of ferricrete precipitates on average linear velocity of the stream infiltrating into the subsurface of Cement Creek and (b) determine when, during the year, the streams were gaining or losing. Thermal probes were constructed by drilling out three $2 \times$ 24-mm holes in a wooden stake and adhering iButtons into the holes with epoxy. The thermal probes were deployed from July 19, 2019 to October 19, 2019 in Cement Creek and May 24, 2019 to October 10, 2019 in Mineral Creek; however, data gaps exist for portions of these time series due to iButton damage during removal of the thermal probes and instances when the stream temperature iButton was not submerged. All temperature data were filtered using a bandpass filter, resampled, and processed in MATLAB according to the temperature time-series analysis developed by Hatch et al. (2006). We calculated average linear velocities into the sediment based upon the amplitude ratio $\left(V_{\text {Ar }}\right)$ and phase shift $\left(V_{\Delta \phi}\right)$ between the shallow and the deep thermal signals and assuming parameters for a saturated, sandy streambed (Hatch et al., 2006, 2010). These parameters included porosity $(\eta=0.35)$, fluid and sediment densities $\left(\rho_{\mathrm{f}}=997 \mathrm{~kg} \mathrm{~m}^{3}\right.$ and $\left.\rho_{\mathrm{s}}=2,650 \mathrm{~kg} \mathrm{~m}^{3}\right)$, fluid and sediment heat capacities $\left(c_{\mathrm{f}}=4,180 \mathrm{~J} \mathrm{~kg}^{-1}{ }^{\circ} \mathrm{C}^{-1}\right.$ and $\left.c_{\mathrm{s}}=800 \mathrm{~J} \mathrm{~kg}^{-1}{ }^{\circ} \mathrm{C}^{-1}\right)$, thermal dispersivity $(\beta \sim 0.001 \mathrm{~m}$ ), and thermal conductivity $\left(\lambda_{0}=1.58 \mathrm{~W} \mathrm{~m}^{-1}{ }^{\circ} \mathrm{C}^{-1}\right)$ (Hatch et al., 2010). Based on field observations of sand-sized grains between streambed cobbles, we assumed that these parameters for a sandy streambed would be representative of the two sites but acknowledge that there are likely heterogeneities in these parameters along the reaches. Negative linear velocities indicate losing conditions (i.e., stream water infiltrates into the streambed), whereas positive linear velocities indicate gaining stream conditions (i.e., groundwater discharges into the stream).

\section{Continuous Salt-Tracer Injection Tests}

Continuous injection salt-tracer tests were conducted to quantify mass transfer parameters and hyporheic zone area. Two tracer tests were conducted at Mineral Creek during baseflow (September) and high flow (July/August) and were compared to high and low flow tracer tests conducted in Cement Creek. During each tracer test, a saltwater solution $(\sim 240 \mathrm{~g} / \mathrm{L} \mathrm{NaCl})$ was injected into the stream at a constant rate for a period of $4 \mathrm{~h}$. The injection rate was determined based on stream discharge at the time of the tracer test (Supplementary Table 1). Prior to the baseflow tracer test, the stream discharge in MC-Fen $\left(Q \sim 0.12 \mathrm{~m}^{3} \mathrm{~s}^{-1}\right.$ ) was similar to the discharge measured prior to the low flow tracer test in Cement Creek ( $Q \sim 0.15 \mathrm{~m}^{3} \mathrm{~s}^{-1}$ ), and the specific conductivity was $\sim 450$ and $1,090 \mu \mathrm{s} / \mathrm{cm}$ at MC-Fen and CC-PG, respectively. Prior to the high flow tracer test, the stream discharge in MC-Fen and CC-PG were 2.2 and $1.1 \mathrm{~m}^{3} \mathrm{~s}^{-1}$, respectively, and the specific conductivity was $\sim 120$ and $440 \mu \mathrm{s} / \mathrm{cm}$, respectively (Supplementary Table 1). Specific conductivity was measured every minute during the tracer test using fluid electrical conductivity loggers (HOBO U-24, Onset Computing). One conductivity logger was deployed upstream of the saltwater injection point to measure background fluid conductivity, and three conductivity loggers were deployed downstream (200, 475 , and $680 \mathrm{~m}$ in MC-Fen; Figures 1D,E) of the tracer mixing zone. Based on previous estimates of approximate mixing zone lengths of 25 times the stream width (Day, 1977), the loggers at $225 \mathrm{~m}$ in MC-Fen and $185 \mathrm{~m}$ in CC-PG were launched at these locations to ensure adequate mixing of the stream and the tracer.

Stream water samples for analysis of $\mathrm{Cl}^{-}, \mathrm{SO}_{4}^{2-}$, and $\mathrm{Na}^{+}$ concentrations were collected during the arrival of the tracer $200 \mathrm{~m}$ downstream of the MC-Fen injection point and $700 \mathrm{~m}$ downstream of the CC-PG injection point. The timing of grab-sample collection was based upon continuous conductivity measurements using a handheld meter (Orion Star A325). Samples were collected during the arrival of the tracer, every 30 min during the breakthrough curve plateau, and during the recession of the tracer until stream conductivity returned to background conditions. The samples were collected in Whatman vials, filtered ( $<0.2 \mu \mathrm{m}$, Nylon), and frozen until analysis using ion chromatography for anions (Dionex ICS-2100) and cations (Dionex ICS-1100).

Transport parameters were determined at high and low flow for both study reaches using the one-dimensional transport with inflow and storage (OTIS) model (Runkel, 1998) coupled with the parameter estimation (PEST) model (Doherty, 2010). OTIS compartmentalizes the system into the main stream channel and the transient storage zone and operates under the primary assumptions that (a) mass is conserved, (b) solute concentration only varies in the longitudinal direction, and (c) transient storage is the only physical process affecting solute concentration in the transient storage zone (Runkel, 1998). The models were constrained using conductivity timeseries data, measured $\mathrm{Cl}^{-}$concentrations, and stream discharge measurements. Air bubbles near the conductivity sensor led to noise in the sensor measurements. To remove the noise, 
the conductivity time-series data were filtered using the robust locally weighted scatterplot smoothing (RLOWESS) filter and smoothdata function in MATLAB using a 10 -min window. The data were then sampled every $10 \mathrm{~min}$ to reduce the dataset size prior to importing into PEST. The models then solved for the best-fit area of hyporheic fluid exchange $\left(A_{\mathrm{s}}\right)$, rate of mass transfer between the stream and hyporheic zone $(\alpha)$, dispersion coefficient $(D)$, lateral inflows $\left(q_{\text {lat }}\right)$, and concentration of lateral inflows $\left(c_{\text {lat }}\right)$.

Additional metrics were calculated to allow for direct comparison of the two stream reaches by normalizing the model estimates to stream characteristics such as discharge and crosssectional area. Storage zone residence time $\left(T_{\text {sto }}\right)$, which gives the average time a water molecule remains in transient storage, was calculated from the modeled parameters,

$$
T_{\text {sto }}=\frac{A_{s}}{A \alpha}
$$

where $A$ is the stream area. We also calculated the hydraulic retention factor $\left(R_{\mathrm{h}}\right)$ as

$$
R_{h}=\frac{A_{s}}{Q}
$$

which represents the storage-zone residence time relative to the hydraulic turnover length (e.g., discharge, Q) (Morrice et al., 1997; Wondzell, 2006) and the average distance a molecule travels before entering the storage zone $\left(L_{\mathrm{s}}\right)$,

$$
L_{s}=\frac{u}{\alpha}
$$

where $u$ is the stream water velocity as well as the proportion of the median travel time resulting from transient storage $\left(F_{\text {med }}\right)$,

$$
F_{\text {med }} \cong\left[1-e^{-L(\alpha / u)}\right] \frac{A_{s}}{A+A_{s}}
$$

which quantifies the movement of the tracer into the storage zone relative to the total mass transport (Runkel, 2002). Furthermore, we can determine the relative importance of transient storage and advective velocity using the Damkohler index (Da) as follows:

$$
D a=\frac{\propto\left(1+\frac{A}{A_{s}}\right) L}{u}
$$

where $L$ is the reach length (Wagner and Harvey, 1997). The experimental $\mathrm{Da}$ also reflects if the model estimates for transient storage zone parameters are reasonable (Wagner and Harvey, 1997). Da on the order of 1 indicates minimum uncertainty in $\alpha$ and $A_{\mathrm{s}}$ (Wagner and Harvey, 1997).

\section{Stream, Groundwater, and Hyporheic Zone Sampling}

Independent of the tracer tests, water samples were collected from the stream channel near the hyporheic zone well clusters at Mineral Creek $(n=8)$ and at Cement Creek $(n=10)$ from February to November 2019, when weather conditions allowed. Shallow groundwater samples were collected from a private well in Mineral Creek (referred to herein as the Artist's Cabin well, $n=1$; Figure 1E) and from a shallow well (120 cmbgl) installed in the iron fen adjacent to the hyporheic zone well clusters in Cement Creek ( $n=3$; Figure 1D). One sample was collected from a fen wetland pool in the Chattanooga Fen complex at Mineral Creek (Figure 1E). Two samples from the Koehler Tunnel discharge and one from Prospect Gulch inflow near Cement Creek (Figure 1C) were collected for comparison to historical data.

The hyporheic zone was sampled directly twice during high flow (June 2019 and 2020) and once during low flow conditions (September 2019) from the hyporheic zone well clusters installed at MC-Fen and CC-PG (Figures 1D,E). The wells settled for 2-4 weeks before the first sampling event. Prior to collecting the water samples, each shallow well was purged at a low flow rate until the measurements of $\mathrm{pH}$, temperature, and specific conductivity stabilized (USEPA, 2010). After these measurements stabilized, water samples were collected for analysis of total and dissolved metals, major anions, and total organic carbon (described below). Ferrous iron $\left(\mathrm{Fe}^{2+}\right)$ and dissolved oxygen (DO) were measured immediately in the field using a portable spectrophotometer (HACH DR1900). $\mathrm{Fe}^{2+}$ was determined using 1,10-phenathroline reagent (HACH Method 8146), and DO was determined using AccuVac Ampules (HACH Method 8166).

During each sampling campaign, measurements of $\mathrm{pH}$, conductivity, and temperature were made using an Orion Star A325. The alkalinity measurements were made in the field using a field kit (HACH Model AL-DT). All water samples were collected according to standard methods (Clesceri et al., 1999). Total metals (unfiltered) and dissolved metals (defined here as $<0.2 \mu \mathrm{m}$ ) were collected in acid-washed polypropylene sample bottles and acidified to $\mathrm{pH}<2$ with trace-metal-grade nitric acid. Samples for major anions were collected in Whatman vials and filtered to $<0.2 \mu \mathrm{m}$ (Nylon). Total organic carbon (TOC) samples were collected in amber glass vials (combusted at $400^{\circ} \mathrm{C}$ ) and preserved with hydrochloric acid to $\mathrm{pH}<2$. All samples were kept on ice in the field and frozen (e.g., anion and metal samples) or refrigerated (e.g., TOC samples) within $6 \mathrm{~h}$ of sample collection.

\section{Geochemical Analyses and Calculations}

The stream, groundwater, and hyporheic zone water samples were analyzed for total and dissolved metals, including Al, As, B, $\mathrm{Ba}, \mathrm{Be}, \mathrm{Ca}, \mathrm{Cd}, \mathrm{Cu}, \mathrm{Cr}, \mathrm{Fe}, \mathrm{K}, \mathrm{Li}, \mathrm{Mg}, \mathrm{Mn}, \mathrm{Mo}, \mathrm{Na}, \mathrm{Ni}, \mathrm{P}, \mathrm{S}, \mathrm{Sb}, \mathrm{Se}$, $\mathrm{Si}, \mathrm{Sn}, \mathrm{Sr}, \mathrm{Ti}, \mathrm{Tl}, \mathrm{V}$, and Zn, using an inductively coupled plasmaoptical emission spectrometer (ICP-OES, Perkin-Elmer Optima $5,300 \mathrm{DV})$ at Colorado School of Mines (Mines). Major anions $\left(\mathrm{Br}^{-}, \mathrm{Cl}^{-}, \mathrm{F}^{-}, \mathrm{NO}_{2}^{-}, \mathrm{NO}_{3}^{-}, \mathrm{SO}_{4}^{2-}\right.$, and $\left.\mathrm{PO}_{4}^{3-}\right)$ were analyzed using ion chromatography (Dionex ICS-2100) with an IonPac AS-11 analytical column $(2 \times 250 \mathrm{~mm})$ at Mines. The TOC samples were analyzed by a Shimadzu TC-Analyzer at the Mines Advanced Water Technology Center.

Mineral saturation indices were calculated for stream and hyporheic zone water samples using PHREEQC with the WATEQ4F database (Ball and Nordstrom, 1987; Parkhurst and 

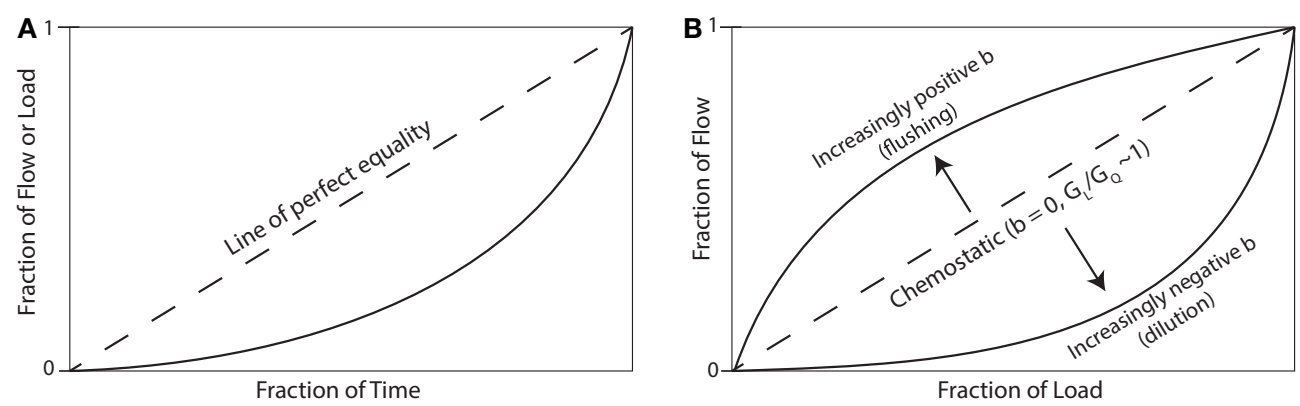

FIGURE 2 | Schematics of (A) Lorenz curves and (B) dual Lorenz curves for load versus flow, as modified from Jawitz and Mitchell (2011) and Gall et al. (2013). The shape of the curves are determined by the Gini coefficient for load and discharge, where perfect equality is $G=0$ and perfect inequality is $G=1$, and can be used to indirectly evaluate concentration-discharge relationships.
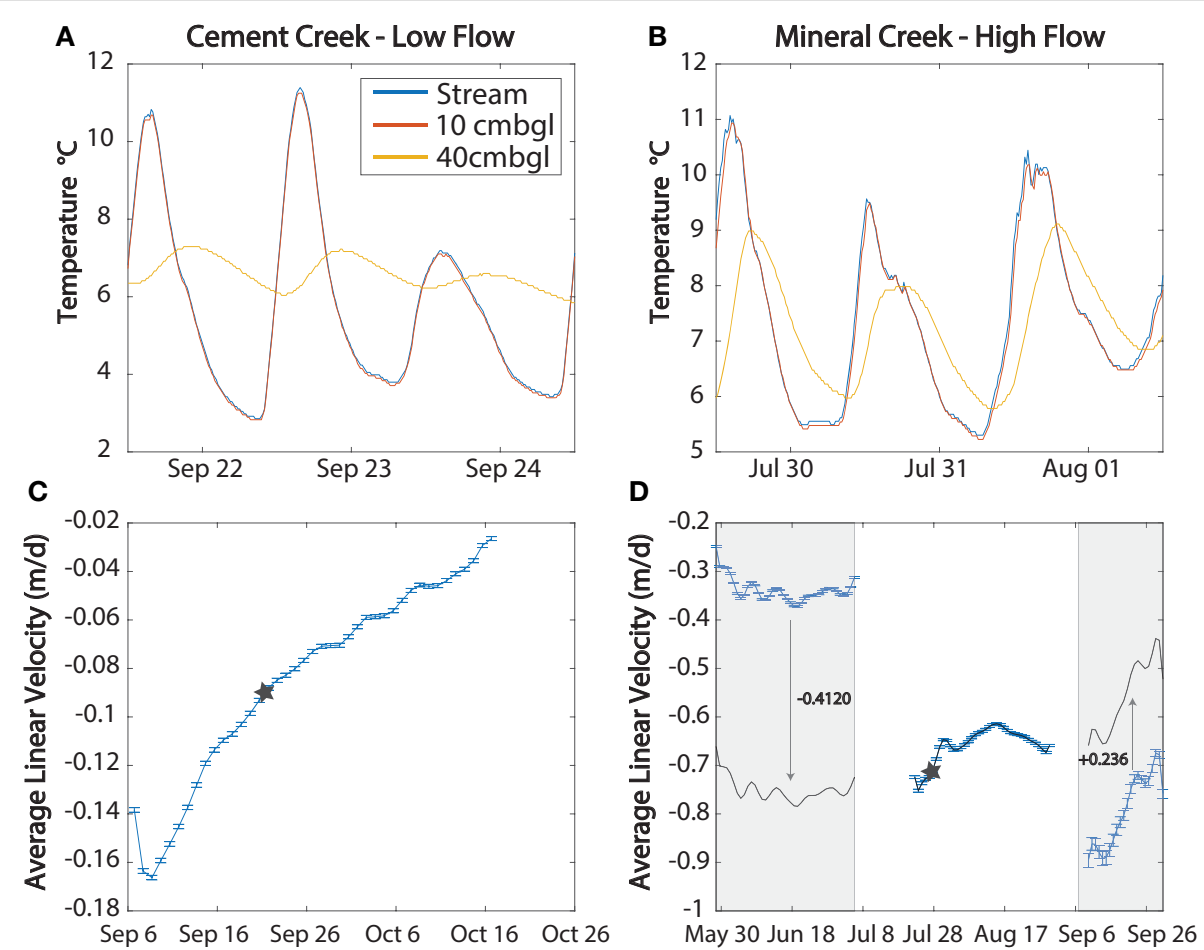

FIGURE 3 | Temperature time-series data for (A) Cement Creek-Prospect Gulch during the low-flow tracer test and (B) Mineral Creek-Chattanooga Fen during the high-flow tracer test, as well as average linear velocity estimates based on amplitude ratios ( $V_{\text {Ar }}$ ) (Hatch et al., 2006) for (C) Cement Creek and (D) Mineral Creek in 2019. Data are not presented for the high-flow tracer test in Cement Creek due to temperature sensor damage and loss of data. The black stars indicate the average linear velocity at the approximate time of the tracer tests. Note that the thermal sensors were removed from Mineral Creek on September 26, before the tracer test was completed on September 28. The blue dashed lines represent uncertainty in the average linear velocity estimates. Negative velocities indicate water fluxes from the stream into the subsurface (e.g., losing stream conditions). The gray-shaded areas in (D) indicate high uncertainty velocity estimates given that the estimates were calculated only from stream temperature and $10 \mathrm{cmbgl}$ temperature sensors due to damage of the $40 \mathrm{cmbgl}$ temperature sensor. Values on plot (D) represent the offset used to correct the Mineral Creek average linear velocity estimates in the shaded regions to the estimates made for the July-August data. We subtracted 0.412 $\mathrm{m} /$ day from all velocity estimates measured from May 30 to July 7 and added $0.236 \mathrm{~m} /$ day to all estimates made in September, assuming that the measurements made during these time periods were offset from the low uncertainty velocity estimates measured from July 8 through August.

Appelo, 2013). The dissolution reaction and associated solubility product for schwertmannite was added to the database (Bigham et al., 1990). We calculated saturation indices for minerals previously identified using $\mathrm{x}$-ray diffraction in Cement Creek and Mineral Creek (Vincent et al., 2007; Wirt et al., 2007; Yager and Bove, 2007) and using measurements from this study of $\mathrm{pH}$, temperature, alkalinity, DO, and dissolved concentrations of major ions and trace metal(loid)s. All water samples were chargebalanced using chloride for geochemical modeling; however, the charge balance error was less than $5 \%$ for all samples, except the 
Mineral Creek $40 \mathrm{cmbgl}$ samples for high and low flow in 2019 $(<10 \%)$ and several samples collected in $2020(<20 \%)$.

\section{Compilation of Historic Data and CQ Analysis}

To determine the influence of variable streamflow on solute fluxes, we compiled historical streamflow and geochemical data for locations nearby the MC-Fen and CC-PG sampling locations. Data were compiled for redox-sensitive elements, including total and dissolved concentrations of $\mathrm{Al}, \mathrm{As}, \mathrm{Cu}, \mathrm{Fe}, \mathrm{Mn}$, and $\mathrm{SO}_{4}^{2-}$. Four samples of stream chemistry and streamflow were compiled from recent US EPA reports (USEPA, 2016, 2017) for MC-Fen. For the CC-PG reach, a total of 10 geochemical samples and corresponding streamflow measurements were compiled from Johnson et al. (2007) and one from a US EPA report (site no. CC27) (USEPA, 2017). These historic data were combined with the samples collected for this study in 2019 to assess concentration-discharge relationships for MC-Fen (total sample count of 10) and CC-PG (total sample count of 20).

A CQ analysis was performed using the compiled datasets for the MC-Fen and CC-PG locations (using historic and new data) to assess potential influences of hyporheic processes on metal(loid) export. A power-law slope (b) was calculated by plotting the concentrations $(C)$ of each redox-sensitive element against the corresponding discharge $(Q)$ in log-log space (e.g., Godsey et al., 2009). The coefficient of variation of each redoxsensitive element $\left(\mathrm{CV}_{C}\right)$ was normalized to the coefficient of variation of the discharge $\left(\mathrm{CV}_{Q}\right)$ to determine the variability in concentration with respect to discharge (Thompson et al., 2011; Musolff et al., 2015). The use of $b$ alone to interpret chemostatic behavior, when concentration is invariant with changes in discharge, can be misleading because concentration variability could be high even in cases where $b< \pm 0.1$ (Thompson et al., 2011; Musolff et al., 2015). Chemostatic solute behavior is defined here as $b \leq \pm 0.1$ and $\mathrm{CV}_{\mathrm{C}} / \mathrm{CV}_{\mathrm{Q}} \leq 0.2$. We characterize solutes as moderately chemodynamic when $0.2<\mathrm{CV}_{\mathrm{C}} / \mathrm{CV}_{\mathrm{Q}} \leq 1$ and chemodynamic when $\mathrm{CV}_{\mathrm{C}} / \mathrm{CV}_{\mathrm{Q}}>1$ 1.0. Gini coefficients, which are a measure of inequality, were calculated to determine the temporal inequality of loads $\left(G_{\mathrm{L}}\right)$ and discharge $\left(G_{\mathrm{Q}}\right)$ for Lorenz curves, which relate the cumulative proportion of a variable [in this case, streamflow $(Q)$ or solute load $(C)$ ] and the cumulative proportion of the population (in this case, time; Figure 2A) (Jawitz and Mitchell, 2011). For example, chemostatic behavior would result in load inequality $\left(G_{\mathrm{L}}\right.$ ) controlled primarily by discharge inequality $\left(G_{\mathrm{Q}}\right)$ because variability in concentration is low compared to variability in discharge and thus $G_{\mathrm{L}} / G_{\mathrm{Q}} \approx 1$ (Figure 2B).

\section{RESULTS AND DISCUSSION}

\section{Physical Characteristics of Streambed Determine Stream-Groundwater Connectivity}

Transport modeling of the tracer test data, in combination with measurements of hydraulic conductivity and average linear velocities, elucidate the physical controls on the hyporheic zone at Mineral Creek and Cement Creek. According to temperature time-series data, both stream reaches were losing (e.g., negative average linear velocities) during all time periods observed (Figure 3); however, the stream velocity into the subsurface was greater at MC-Fen $(-0.7$ to $-0.5 \mathrm{~m} /$ day, Figure $3 \mathrm{D})$ compared to CC-PG $(-0.16$ to $-0.03 \mathrm{~m} /$ day; Figure $3 \mathrm{C})$. Vertical hydraulic gradients $(d h / d z)$ measured in the hyporheic zone well clusters also reflected losing stream conditions, where hydraulic heads were greater in the shallower well-compared to the deep well at both sites (Supplementary Table 2). The lower linear velocity at CC-PG was consistent with the lower hydraulic conductivity at depth $\left(\sim 4 \times 10^{-5} \mathrm{~m} / \mathrm{s}\right.$ at low flow and $8 \times 10^{-5}$ at high flow in the $39 \mathrm{cmbgl}$ well) compared to the higher linear velocities and hydraulic conductivity at depth in the MC-Fen reach $\left(\sim 9 \times 10^{-5}\right.$ $\mathrm{m} / \mathrm{s}$ at low flow and $1 \times 10^{-4}$ at high flow in the $63 \mathrm{cmbgl}$ well) based on slug test data (Supplementary Table 3).

The physical differences in average linear velocities and hydraulic conductivity of the streambeds in the MC-Fen and CC$P G$ reaches influenced the hyporheic storage and mass transfer rates between the stream and the transient storage zones. Model estimates of mass transfer parameters using PEST with OTIS and the tracer data (Supplementary Figure 2) measured at the hyporheic zone well clusters (e.g., $200 \mathrm{~m}$ downstream of the injection site for MC-Fen and $700 \mathrm{~m}$ downstream of the injection site for CC-PG) indicated that hyporheic storage $\left(A_{\mathrm{S}}\right)$ and the proportion of solute storage in the hyporheic zone compared to the stream $\left(A_{\mathrm{s}} / A\right)$ were greater at high flow and low flow in MCFen compared to CC-PG (Table 1, Supplementary Figures 3, 4). Thus, the smaller hyporheic zone areas of $0.1 \mathrm{~m}^{2}$ at low flow and $0.4 \mathrm{~m}^{2}$ at high flow for CC-PG were consistent with low average linear velocities and less permeable sediments, whereas the larger hyporheic zone areas of $0.6 \mathrm{~m}^{2}$ at low flow and $1.8 \mathrm{~m}^{2}$ at high flow for MC-Fen were associated with high average linear velocities and more permeable sediments. It is important to note that we observed surface-flow contributions from hillslope tributaries to MC-Fen that likely caused a variable discharge along the reaches investigated and caused a lag between the measured and the modeled breakthrough curves for the low flow tracer tests. To minimize this lag, the stream discharge in OTIS was adjusted for the low flow tracer test to improve model fits (Table 1). The root mean square error of the data-model fit was relatively low for all simulations ( $\sim 11$ to 43 ; Table 1), indicating that model estimates were representative of the breakthrough curves. However, the mass transfer rate $(\alpha)$ was less sensitive to model output than $A_{\mathrm{s}}$, and estimates of $\alpha$ were similar across site and flow regime $(0.001$ $<\alpha<0.005 \mathrm{~s}^{-1}$ ).

\section{Cement Creek as a Model of Poorly Connected Groundwater-Stream Systems}

In the CC-PG well cluster, the dissolved concentrations of $\mathrm{Cl}^{-}, \mathrm{Li}^{+}$, and $\mathrm{Ca}^{2+}$ varied with depth during high flow in 2019, as indicated by the high coefficients of variation (CV) for these solutes (111, 56.6, and 23.4\%, respectively; Table 2). Furthermore, the percent difference between high flow and low flow in dissolved concentrations of $\mathrm{Li}^{+}, \mathrm{Ca}^{2+}$, and $\mathrm{Na}^{+}$for the stream and shallowest well $(23 \mathrm{cmbgl})$, and dissolved $\mathrm{Cl}^{-}$for the shallowest well only, was greater compared to the middle 
TABLE 1 | One-dimensional transport with inflow and storage with parameter estimation (PEST) model constraints, model outputs, and calculated transient storage zone parameters [data were filtered prior to entry into PEST using a robust locally weighted smoothing filter (RLOWESS)].

\begin{tabular}{|c|c|c|c|c|c|c|c|c|c|c|c|c|c|c|c|c|c|}
\hline \multirow[t]{2}{*}{ Stream reach } & \multicolumn{3}{|c|}{ Field measurements } & \multicolumn{2}{|l|}{ Model inputs } & \multicolumn{6}{|c|}{ Model estimates and RMSE } & \multicolumn{6}{|c|}{ Calculated } \\
\hline & $\begin{array}{l}\text { Measured discharge } \\
\mathrm{m}^{3} \mathrm{~s}^{-1}\end{array}$ & $\begin{array}{c}u \\
\mathrm{~m} \mathrm{~s}^{-1}\end{array}$ & $\mathrm{pH}$ & $\begin{array}{l}\text { Adjusted discharge }{ }^{a} \\
\qquad \mathrm{~m}^{3} \mathrm{~s}^{-1}\end{array}$ & $\begin{array}{c}A \\
\mathrm{~m}^{2}\end{array}$ & $\begin{array}{c}Q_{\text {lat-in }}{ }^{b} \\
m^{3} s^{-1} m^{-1}\end{array}$ & $C_{\text {lat-in }}$ & $\begin{array}{l}A_{\mathrm{s}} \\
\mathrm{m}^{2}\end{array}$ & $\begin{array}{c}D \\
\mathrm{~m}^{2} \mathrm{~s}^{-1}\end{array}$ & $\begin{array}{c}\alpha \\
\mathbf{s}^{-1}\end{array}$ & RMSE $^{\mathrm{C}}$ & $A_{\mathrm{s}} / A$ & Da & $\begin{array}{c}T_{\text {sto }} \\
\mathrm{h}\end{array}$ & $\begin{array}{c}R_{\mathrm{h}}^{\mathrm{d}} \\
\mathrm{s} \mathrm{m}^{-1}\end{array}$ & $\begin{array}{l}L_{\mathrm{s}} \\
\mathrm{m}\end{array}$ & $\begin{array}{c}F_{\text {med }} \\
\%\end{array}$ \\
\hline \multirow[t]{2}{*}{ Mineral Creek at Chattanooga } & 0.12 & 0.14 & 6.5 & 0.20 & 0.86 & $9.0 \times 10^{-7}$ & 46 & 0.60 & 0.2 & 0.004 & 42.5 & 0.70 & 2.9 & 2.8 & 3.00 & 55 & 40.6 \\
\hline & 2.2 & 1.0 & 6.8 & n.a. & 2.2 & $1.0 \times 10^{-4}$ & 8.3 & 1.8 & 0.1 & 0.005 & 10.5 & 0.82 & 0.9 & 2.7 & 0.82 & 200 & 30.4 \\
\hline \multirow[t]{2}{*}{ Cement Creek at Prospect Gulch } & 0.18 & 0.45 & 3.9 & 0.26 & 0.62 & $9.7 \times 10^{-6}$ & 49 & 0.10 & 0.8 & 0.001 & 23.6 & 0.16 & 0.1 & 2.7 & 0.36 & 450 & 11.8 \\
\hline & 1.3 & 0.68 & 5.2 & n.a. & 1.6 & $5.0 \times 10^{-6}$ & 25 & 0.40 & 0.09 & 0.001 & 17.1 & 0.25 & 0.1 & 4.1 & 0.36 & 680 & 14.2 \\
\hline
\end{tabular}

u, stream velocity; A, stream cross-sectional area; Qlat-in, discharge of lateral inflows; $C_{l a t-i n}$, concentration of lateral inflows; $A_{s}$, transient storage zone cross-sectional area; $D$, dispersion; $\alpha$, mass transfer rate; Da, Damkohler number;

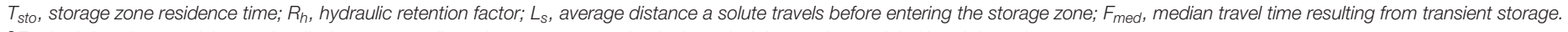

${ }^{a}$ For both low-flow model runs, the discharge was adjusted to account for a lag in the arrival time of the modeled breakthrough curve.

${ }^{b}$ The boundary condition for $\mathrm{Q}_{\text {lat-out }}\left(\mathrm{m}^{3} \mathrm{~s}^{-1} \mathrm{~m}^{-1}\right)$ was set to 0.

${ }^{c}$ Root mean square error $(R M S E)=\sqrt{\sum_{i=1}^{n}(\text { residual })^{2}}$.

${ }^{d}$ Hydraulic retention factor $\left(R_{h}\right)$ was calculated using the adjusted discharge values, when applicable.

TABLE 2 | Average, standard deviation, and coefficient of variation for dissolved concentrations of conservative elements as a function of depth in the hyporheic zone well clusters.

\begin{tabular}{|c|c|c|c|c|c|c|c|c|c|c|}
\hline \multirow[t]{2}{*}{ Site } & \multirow[t]{2}{*}{ Solute } & \multicolumn{3}{|c|}{ High flow 2019} & \multicolumn{3}{|c|}{ Low flow 2019} & \multicolumn{3}{|c|}{ High flow 2020} \\
\hline & & Average $^{a}$ & $\begin{array}{l}\text { Standard } \\
\text { deviation }\end{array}$ & $\begin{array}{c}\text { Coefficient } \\
\text { of variation } \\
(\%)\end{array}$ & Average $^{a}$ & $\begin{array}{l}\text { Standard } \\
\text { deviation }\end{array}$ & $\begin{array}{c}\text { Coefficient } \\
\text { of variation } \\
(\%)\end{array}$ & Average $^{a}$ & $\begin{array}{l}\text { Standard } \\
\text { deviation }\end{array}$ & $\begin{array}{c}\text { Coefficient } \\
\text { of variation } \\
(\%)\end{array}$ \\
\hline \multirow[t]{4}{*}{ Cement Creek } & $\mathrm{Cl}$ & 16.4 & 18.2 & 111 & 5.84 & 2.59 & 44.4 & 9.72 & 3.22 & 33.1 \\
\hline & $\mathrm{Li}$ & 2.16 & 1.22 & 56.6 & 2.31 & 0.11 & 4.67 & 0.84 & 0.51 & 60.5 \\
\hline & $\mathrm{Ca}$ & 2.65 & 0.62 & 23.4 & 3.69 & 0.49 & 13.4 & 1.92 & 0.62 & 32.0 \\
\hline & $\mathrm{Na}$ & 78.2 & 8.93 & 11.4 & 111 & 10.5 & 9.46 & 82.9 & 19.6 & 23.6 \\
\hline \multirow[t]{4}{*}{ Mineral Creek } & $\mathrm{Cl}$ & 20.8 & 1.14 & 5.49 & 17.5 & 2.10 & 12.0 & 22.1 & 3.05 & 13.8 \\
\hline & $\mathrm{Li}$ & $<0.7$ & NA & NA & $<0.7$ & NA & NA & $0.68^{b}$ & 0.16 & 23.4 \\
\hline & $\mathrm{Ca}$ & 0.34 & 0.05 & 13.7 & 2.10 & 0.05 & 2.38 & 0.36 & 0.06 & 16.6 \\
\hline & $\mathrm{Na}$ & 59.5 & 9.09 & 15.3 & 210 & 16.8 & 7.97 & 52.20 & 7.22 & 13.8 \\
\hline
\end{tabular}

${ }^{a}$ Average dissolved concentrations are reported in units of $\mu \mathrm{M}$ for $\mathrm{Cl}$, Li, and $\mathrm{Na}$ and units of $\mathrm{mM}$ for $\mathrm{Ca}$.

${ }^{b}$ Duplicate Li analyses on Mineral Creek samples indicated a high error ( \pm 1 ppm) on Li values. 
and deep wells (39 and $53 \mathrm{cmbgl}$, respectively) (Figures 4A,B). The invariability of water chemistry in the middle and deep wells compared to the chemical variability in the shallow well in response to flow suggests a disconnect between the shallow and the deeper two wells. This disconnect is also reflected in the dissolved oxygen concentrations as a function of depth in the CC-PG wells. While the $\mathrm{pH}$ varied by only $\sim 1 \mathrm{pH}$ unit with depth (Figure 4C), the dissolved oxygen concentrations decreased from $\sim 9 \mathrm{mg} / \mathrm{L}$ in the stream to $\sim 2 \mathrm{mg} / \mathrm{L}$ in the deepest well (Figure 4D). Furthermore, a fourfold difference in dissolved oxygen concentrations in the shallow well $(23 \mathrm{cmbgl})$ between low flow $(3.7 \mathrm{mg} / \mathrm{L})$ and high flow conditions $(7.6 \mathrm{mg} / \mathrm{L})$ is consistent with model results from OTIS, where the hyporheic mixing of oxygenated stream water and shallow groundwater was limited to an area $\left(A_{\mathrm{s}}\right)$ of $\sim 0.1 \mathrm{~m}^{2}$ during low flow and $\sim 0.4$ $\mathrm{m}^{2}$ during high flow (Table 1). Given that (a) dissolved $\mathrm{Ca}^{2+}$, $\mathrm{Na}^{+}$, and $\mathrm{Li}^{+}$in the middle and deep wells changed minimally in response to changing stream discharge (percent difference between high flow and low flow of 1.1-18\%), (b) dissolved $\mathrm{Ca}^{2+}$, $\mathrm{Na}^{+}, \mathrm{Li}^{+}$, and $\mathrm{Cl}^{-}$in the stream and shallowest well did change in response to variable stream discharge and fluctuations in hyporheic area (percent difference of $26-1,310 \%$ ), and (c) the middle well was characterized by low hydraulic conductivity and low dissolved oxygen, a physical disconnect between hyporheic mixing that occurs above the middle well and groundwater below the middle well was indicated.

We propose that the physical disconnect between hyporheic mixing and groundwater in CC-PG occurs as a result of ferricrete precipitation at the approximate location of the middle well and the estimated maximum area of hyporheic mixing (40 $\mathrm{cm}^{2}$ ). Hyporheic mixing would facilitate the penetration of oxygenated waters to this depth, where it would mix with reducing groundwaters and trigger the precipitation of minerals that compose ferricrete (Wirt et al., 2007). The potential of ferricrete deposits to serve as a barrier between stream water and groundwater is consistent with previous observations that the reduced permeability from ferricrete cementation of clastic sediments decreases the flow of groundwater near streams and influences streambed geomorphology (Vincent et al., 2007; Wirt et al., 2007).

\section{Mineral Creek as a Model of Well-Connected Groundwater-Stream Systems}

In comparison to CC-PG, the MC-Fen system was characterized by a larger hyporheic storage area (Table 1), higher average linear velocities (Figure 3), and higher hydraulic conductivity (Supplementary Table 3). The behavior of conservative solutes in the subsurface of MC-Fen also differed from CC-PG. The coefficient of variation as a function of depth for dissolved concentrations of $\mathrm{Cl}^{-}, \mathrm{Na}^{+}$, and $\mathrm{Ca}^{2+}$ in the MC-Fen wells under high flow and low flow conditions was $\leq 15 \%$ (compared to $\leq 111 \%$ for CC-PG; Table 2). Similarly, the percent differences in dissolved $\mathrm{Ca}^{2+}, \mathrm{Na}^{+}$, and $\mathrm{Cl}^{-}$were within 10,15 , and $34 \%$, respectively, of each other with depth, and $\mathrm{pH}(6.2-7.3 \mathrm{pH})$ and dissolved oxygen (6.4-10 $\mathrm{mg} / \mathrm{L})$ exhibited no identifiable trend with depth (Figure 4). The dissolved concentrations of $\mathrm{Li}^{+}$ were below detection limits in all samples. While the shallow and deep wells in the CC-PG system were disconnected, both the shallow well chemistry and the deep well chemistry at MCFen responded to flow, where an increase in flow resulted in a decrease in conservative solute concentrations at all depths (Table 2, Supplementary Figure 6). This behavior indicates that groundwater and surface water were well-connected at this site, and this connection facilitated the homogenization of chemistry in the hyporheic zone. Chemical homogenization at MC-Fen was consistent with observations from the East River, where intermittent surface water infiltration and high hydraulic conductivities homogenized the subsurface water chemistry (Nelson et al., 2019; Saup et al., 2019).

\section{Metal(loid) Behavior in the Hyporheic Zone at CC-PG and MC-Fen}

Here we focus on how differences in subsurface mixing processes (as highlighted by the conservative element behavior) influence dissolved metal-sediment interactions in the shallow subsurface at CC-PG and MC-Fen. Although the metal sources at these two sites-Koehler Tunnel and Prospect Gulch-had dissolved and total concentrations of $\mathrm{Al}, \mathrm{Fe}, \mathrm{Mn}$, and $\mathrm{Zn}$ that were the same order of magnitude (Table 4), the average dissolved concentrations of these elements were at least one order of magnitude greater in the stream at CC-PG compared to those in the stream at MC-Fen (Table 3). The metal(loid) concentrations in this study were consistent with measurements of seeps, springs, and draining mines in Prospect Gulch made by the US EPA from 2016 to 2018 (Table 3) and previous water quality surveys by the US EPA at Koehler Tunnel in 2016 and 2017 (Table 3). Furthermore, the dissolved $\mathrm{Al}$, As, Fe, Mn, Pb, and $\mathrm{Zn}$ concentrations were several orders of magnitude greater in a wetland pool in the Chattanooga Fen adjacent to MC-Fen than in the Koehler Tunnel, but these concentrations were not reflected in the stream at MC-Fen. The following sections highlight how a well-connected groundwater-stream system influences the relatively low dissolved $\mathrm{Al}, \mathrm{Fe}$, and $\mathrm{Mn}$ concentrations in Mineral Creek, while a poorly connected groundwater-stream system influences the relatively high $\mathrm{Al}, \mathrm{Fe}$, and $\mathrm{Mn}$ concentrations in CC-PG.

\section{Ferricrete Is an Important Regulator of Metal Concentrations at CC-PG}

The stream and the shallow groundwater at CC-PG were poorly connected, and a ferricrete layer at depth limited the areal extent of the hyporheic zone. The low average linear velocities facilitated low dissolved oxygen fluxes into the subsurface $\left(8.0 \mathrm{~g} / \mathrm{m}^{2} / \mathrm{h}\right.$ $\mathrm{O}_{2(\mathrm{aq})}$ at low flow and $109 \mathrm{~g} / \mathrm{m}^{2} / \mathrm{h} \mathrm{O}_{2(\mathrm{aq})}$ at high flow in 2020), which resulted in a steep decrease in oxygen (Figure 4D) and correspondingly steep metal concentration gradients (Figure 5). Furthermore, the dissolved and total metal concentrations were within error for nearly all samples and metals, which was likely due to the stable and acidic $\mathrm{pH}$ at all depths and over time (Figure 4C). Notable partitioning between dissolved and total $\mathrm{Fe}$ and $\mathrm{Al}$ in the deeper two wells (i.e., in and below the ferricrete layer) was only observed for the 2020 high flow sampling event (Figures 5A,I) and for $\mathrm{Mn}$ at low flow, indicating the limited precipitation of $\mathrm{Al}, \mathrm{Fe}$, and $\mathrm{Mn}$ particulates or colloids. Dissolved 


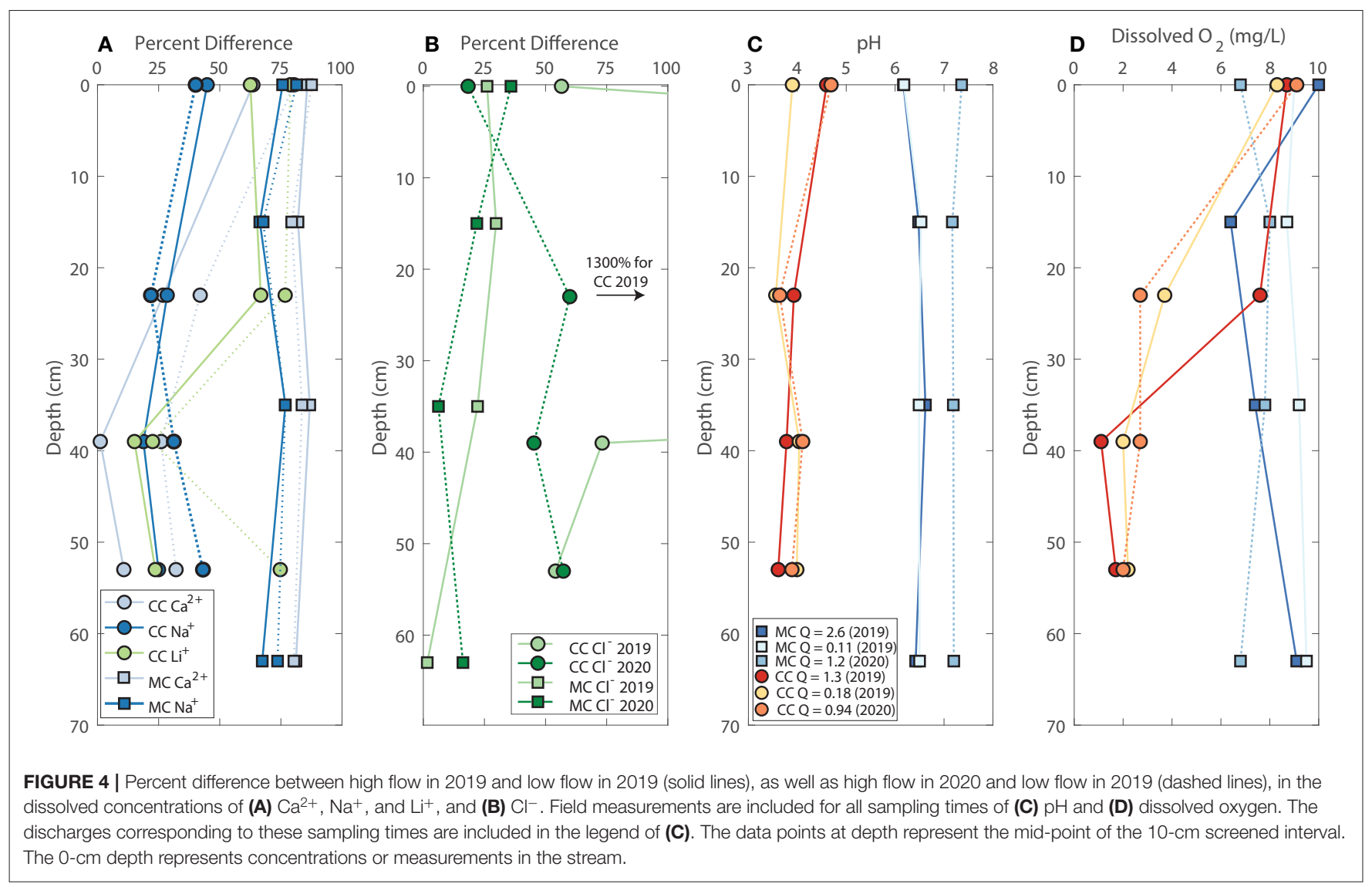

concentrations of $\mathrm{Mn}, \mathrm{SO}_{4}^{2-}$, and $\mathrm{Cu}$, which were sensitive to changes in streamflow in the stream and shallowest well but were insensitive to changes in streamflow near the ferricrete layer and the deepest well, further highlight the disconnect between the shallow hyporheic zone and groundwater at this site. Metals such as $\mathrm{Al}$ and $\mathrm{Fe}$, which increased in dissolved and total concentration with depth until the ferricrete layer and did not change in response to streamflow in the shallowest well, reflect that processes other than stream water infiltration and hyporheic mixing regulated these metal concentrations (Figures 5A,I).

According to saturation index calculations (Table 5) and Eh$\mathrm{pH}$ diagrams (Figure 6), the $\mathrm{Al}$ and $\mathrm{Fe}$ concentrations were buffered by several minerals commonly identified in acid rock drainage environments, such as alunite (Wirt et al., 2007; Yager and Bove, 2007), jurbanite (Anthony and McLean, 1976), and Fe-bearing minerals that typically form ferricrete, such as ferrihydrite, goethite, and schwertmannite (Stanton et al., 2007; Wirt et al., 2007). For dissolved Al, waters were at or near equilibrium (defined here as $\mathrm{SI}< \pm 0.5$ ) with respect to jurbanite and alunite (Table 4). Furthermore, most samples at low flow and at high flow were near equilibrium between $\mathrm{AlSO}_{4}^{+}$and jurbanite on the Eh-pH diagram, based on the $\mathrm{pH}$ measured during sampling and Eh calculated from the $\mathrm{Fe}^{2+} / \mathrm{Fe}^{3+}$ redox couple (Figure 6). Although all samples, except for the stream at low flow, were calculated to be oversaturated (SI $> \pm 0.5$ ) with respect to ferrihydrite, goethite, and schwertmannite (Table 5), the Eh-pH diagram calculations show samples near equilibrium between the schwertmannite and $\mathrm{FeOH}^{2+}$ or $\mathrm{Fe}^{2+}$ species boundary when the iron concentrations are high (dashed line in Figure 6A). Although the measured $\mathrm{pH}$ and calculated Eh levels do not plot directly on this boundary, the equilibrium constants can vary with crystallinity and the age of iron oxide minerals (Schwertmann, 1991), where a change in the equilibrium constant toward a more soluble, freshly precipitated form of iron oxide would shift the position of the dashed line in Figure 6A up toward the plotted data. Thus, we posit that schwertmannite dissolution likely plays a role in buffering iron concentrations in the shallow subsurface of CC-PG, particularly at high flow (Figure 6A). This observation is consistent with the measured increase in dissolved As concentrations with depth at high flow, which may occur as a result of decreased Fe-oxide sediment surfaces and desorption (Smedley and Kinniburgh, 2002). These calculations suggest that $\mathrm{Al}$ - and Fe-bearing minerals regulate dissolved $\mathrm{Fe}$ and $\mathrm{Al}$ concentrations, as well as sorption of metal(loid)s such as arsenic, with depth in the subsurface at Cement Creek.

The small hyporheic zone at CC-PG (Table 1), facilitated by low linear velocities (Figure 3) and a physical disconnect between shallow groundwater and the stream, results in less movement of stream water through the hyporheic zone. For example, the average distance a solute travels in Cement Creek before entering the storage zone $\left(L_{\mathrm{s}}\right)$ was 450 and 
TABLE 3 | Stream chemistry for the samples collected in 2019 adjacent to the hyporheic zone well clusters and used in CQ analysis ${ }^{a}$.

\begin{tabular}{|c|c|c|c|c|c|c|c|c|c|c|c|c|c|c|}
\hline Site name & Sampling date & Filter fraction & $\mathrm{pH}$ & Discharge $^{b}$ & Al & As & Co & $\mathrm{Cu}$ & $\mathrm{Fe}$ & Mn & $\mathrm{Ni}$ & $\mathrm{Pb}$ & $\mathrm{Zn}^{213 c}$ & $\mathrm{SO}_{4}^{2-\mathrm{d}}$ \\
\hline & & & & $\mathrm{m}^{3} / \mathrm{s}$ & $\mu \mathbf{M}$ & $\mu \mathrm{M}$ & $\mu \mathrm{M}$ & $\mu \mathrm{M}$ & $\mu \mathbf{M}$ & $\mu \mathbf{M}$ & $\mu \mathbf{M}$ & $\mu \mathrm{M}$ & $\mu \mathbf{M}$ & $\mathrm{mM}$ \\
\hline \multirow{13}{*}{$\begin{array}{l}\text { Cement Creek at } \\
\text { hyporheic zone } \\
\text { well cluster }\end{array}$} & $5 / 24 / 19$ & Unfiltered & 4 & $0.47^{\mathrm{b}}$ & 116 & 0.21 & 0.28 & 1.36 & 178 & 71.4 & 0.14 & 0.07 & 33 & NA \\
\hline & & $<0.2 \mu \mathrm{m}$ & & & 131 & $<0.11$ & 0.33 & 1.56 & 188 & 81.9 & 0.19 & 0.1 & 37.5 & NA \\
\hline & $6 / 21 / 19$ & Unfiltered & 3.3 & $3.8^{b}$ & 34.9 & $<0.11$ & 0.08 & 1.03 & 51.1 & 12.9 & $<0.02$ & 0.07 & 9.53 & NA \\
\hline & & $<0.2 \mu \mathrm{m}$ & & & 23.7 & $<0.11$ & 0.08 & 1.06 & 25.7 & 13.2 & $<0.02$ & 0.03 & 10.1 & 0.79 \\
\hline & $8 / 1 / 2019^{e}$ & $<0.2 \mu \mathrm{m}$ & 5.2 & 0.99 & 31.1 & 0.22 & 0.15 & 0.48 & 85.4 & 42.5 & 0.12 & 0.05 & 16.6 & NA \\
\hline & 8/7/19 & Unfiltered & 5.1 & 0.75 & 62.6 & 0.17 & 0.24 & 0.62 & 102 & 47.5 & $<0.02$ & 0.08 & 17.9 & 2.51 \\
\hline & & $<0.2 \mu \mathrm{m}$ & & & 43.7 & 0.29 & 0.23 & 0.57 & 93.3 & 48 & $<0.02$ & 0.08 & 18.4 & NA \\
\hline & 8/8/19 & Unfiltered & 5 & 0.78 & 64.8 & 0.27 & 0.24 & 0.77 & 98.3 & 45.6 & $<0.02$ & 0.1 & 18.1 & 2.52 \\
\hline & & $<0.2 \mu \mathrm{m}$ & & & 52.9 & 0.27 & 0.24 & 0.7 & 89.8 & 46.1 & $<0.02$ & 0.02 & 18.2 & NA \\
\hline & $11 / 11 / 19$ & Unfiltered & 4.1 & 0.19 & 171 & 0.49 & 0.45 & 0.5 & 260 & 146 & 0.26 & 0.12 & 44.9 & NA \\
\hline & & $<0.2 \mu \mathrm{m}$ & & & 176 & 0.39 & 0.45 & 0.49 & 254 & 153 & 0.25 & 0.09 & 46.4 & 5.15 \\
\hline & $6 / 10 / 20$ & Unfiltered & 4.7 & 0.94 & 43.1 & 0.3 & NA & 0.89 & 73.7 & 28.9 & 0.12 & $<0.02$ & 16.9 & NA \\
\hline & & $<0.2 \mu \mathrm{m}$ & & & 32.8 & 0.19 & NA & 0.49 & 48.7 & 16.9 & 0.09 & $<0.02$ & 9.7 & 1.71 \\
\hline \multirow{8}{*}{$\begin{array}{l}\text { Mineral Creek at } \\
\text { hyporheic zone } \\
\text { well cluster }\end{array}$} & $5 / 24 / 19$ & Unfiltered & 7.1 & 0.99 & 4.46 & 0.14 & $<0.02$ & 0.38 & 4.69 & 2.13 & $<0.02$ & 0.12 & 6.28 & NA \\
\hline & & $<0.2 \mu \mathrm{m}$ & & & 1.27 & $<0.11$ & $<0.02$ & 0.18 & 0.73 & 1.59 & $<0.02$ & $<0.02$ & 5.07 & NA \\
\hline & $9 / 6 / 19$ & Unfiltered & 7.5 & 0.24 & 0.64 & 0.19 & $<0.02$ & $<0.09$ & 0.43 & 0.8 & $<0.02$ & 0.08 & 3.2 & NA \\
\hline & & $<0.2 \mu \mathrm{m}$ & & & 0.23 & 0.18 & $<0.02$ & $<0.09$ & 0.08 & 0.75 & $<0.02$ & 0.05 & 3.23 & NA \\
\hline & $11 / 11 / 19$ & Unfiltered & 7.3 & 0.07 & 0.63 & 0.39 & $<0.02$ & $<0.09$ & 0.31 & 0.53 & $<0.02$ & $<0.02$ & 4.04 & $\mathrm{NA}$ \\
\hline & & $<0.2 \mu \mathrm{m}$ & & & 0.53 & 0.2 & 0.02 & $<0.09$ & 0.13 & 0.54 & $<0.02$ & 0.03 & 4.23 & 3.54 \\
\hline & 6/9/20 & Unfiltered & 7.4 & 1.2 & 3.15 & 0.17 & NA & 0.2 & 3.6 & 1.05 & 0.04 & 0.05 & 2.5 & $\mathrm{NA}$ \\
\hline & & $<0.2 \mu \mathrm{m}$ & & & 0.67 & 0.14 & NA & $<0.09$ & 0.58 & 0.57 & 0.04 & 0.04 & 1.55 & 0.36 \\
\hline Detection limit & & & & & 0.04 & 0.11 & 0.02 & 0.09 & 0.03 & 0 & 0.02 & 0.02 & 0.04 & 0.46 \\
\hline
\end{tabular}

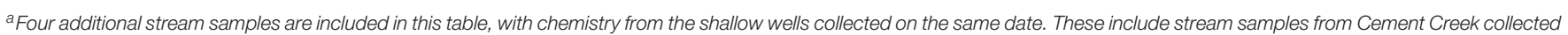

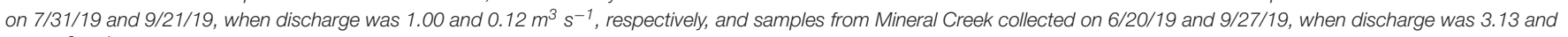
$0.12 \mathrm{~m}^{3} \mathrm{~s}^{-1}$, respectively.

${ }^{b}$ These discharge values were measured upstream at the CCSG1 stilling well, given that these samples were collected prior to the installation of the stilling well near Prospect Gulch.

${ }^{c} 213$ represents the wavelength of measurement for ICP-OES (in $\mathrm{nm}$ ).

${ }^{d} \mathrm{SO}_{4}^{2-}$ was measured for filtered samples only.

${ }^{e}$ Not used in concentration-discharge analysis.

$680 \mathrm{~m}$, and the median travel time resulting from transient storage $\left(F_{\text {med }}\right)$ was 12 and $14 \%$ at high flow and at low flow, respectively. This indicates that water in the shallow subsurface has more time to react before being replenished with new infiltrating stream water, which allows for more reaction time with subsurface sediments. Thus, we conclude that poorly connected systems with a small hyporheic zone facilitate the formation of strong redox and metal concentration gradients and enhance metal-sediment interactions (Figure 7A).

\section{Connected Stream-Groundwater System Facilitates Colloid and Precipitate Formation}

Unlike for CC-PG, where metal concentrations were predominantly in the dissolved phase $(<0.2 \mu \mathrm{m})$, the total metal concentrations (unfiltered) in the wells of MC-Fen were several orders of magnitude greater than the dissolved concentrations of $\mathrm{Al}, \mathrm{Cu}, \mathrm{Fe}$, and $\mathrm{Mn}$ at all depths within the hyporheic zone (Figures 5C,D,H,K). Furthermore, dissolved oxygen penetrated to a depth of at least $70 \mathrm{~cm}$ (Figure 4D), dissolved oxygen fluxes were two orders of magnitude greater $\left(170\right.$ and $110 \mathrm{~g} / \mathrm{m}^{2} / \mathrm{h} \mathrm{O}$ (aq) at high flow and at low flow, respectively) compared to CC-PG, and dissolved $\mathrm{Al}, \mathrm{Cu}, \mathrm{Fe}$, and $\mathrm{Mn}$ concentrations remained low as a function of depth (Figure 5). Saturation indices and stability diagrams indicate that the waters were oversaturated with respect to minerals such as goethite, $\mathrm{Fe}(\mathrm{OH})_{3(\mathrm{a})}$, and manganite, as well as alunite during high flow in 2019 (Table 5, Figure 6B, Supplementary Figure 7). The formation of metal colloids and precipitates would decrease dissolved metal concentrations relative to the conservative elements, which were invariable as a function of depth (Figure 4, Supplementary Figure 6). Higher concentrations of $\mathrm{Al}, \mathrm{Cu}, \mathrm{Fe}$, and $\mathrm{Mn}$ in unfiltered samples compared to filtered samples indicate the presence of some colloidal and precipitated metals, consistent with the deep penetration of oxygen in the subsurface (Figure 4D). We posit that the mixing of metal-rich groundwater with oxygen-rich stream water in the hyporheic zone of MC-Fen, facilitated by high linear velocities and a large hyporheic area, triggers the precipitation of metal oxides in the subsurface (Figure 7B). Furthermore, the higher total metal concentrations with depth at high flow compared to those at low flow (Figure 5) suggest that colloid and precipitate formation is enhanced at high flow when the groundwater level is higher (Supplementary Table 2) and the hyporheic zone is larger (Table 1). 
TABLE 4 | Groundwater, metal(loid) source, and iron fen trace metal(loid) and sulfur chemistry, including historical data from Koehler Tunnel and Prospect Gulch collected by the Environmental Protection Agency.

\begin{tabular}{|c|c|c|c|c|c|c|c|c|c|c|c|c|c|c|c|}
\hline \multirow[t]{2}{*}{ Sample site } & \multirow[t]{2}{*}{ Sampling date } & \multirow[t]{2}{*}{ Filter fraction } & \multirow[t]{2}{*}{$\mathrm{pH}$} & \multirow{2}{*}{$\begin{array}{c}\text { Dissolved oxygen } \\
\text { mg/L }\end{array}$} & \multirow{2}{*}{$\frac{\mathrm{Fe}^{2+}}{\mathrm{mg} / \mathrm{L}}$} & Al & \multirow{2}{*}{$\begin{array}{l}\text { As } \\
\text { uM }\end{array}$} & \multirow{2}{*}{$\begin{array}{l}\text { Co } \\
\text { uM }\end{array}$} & \multirow{2}{*}{$\begin{array}{l}\mathrm{Cu} \\
\mathrm{uM}\end{array}$} & \multirow{2}{*}{$\begin{array}{l}\mathrm{Fe} \\
\mathrm{uM}\end{array}$} & \multirow{2}{*}{$\begin{array}{l}\mathrm{Mn} \\
\mathrm{uM}\end{array}$} & \multirow{2}{*}{$\begin{array}{l}\mathrm{Ni} \\
\mathrm{uM}\end{array}$} & \multirow{2}{*}{$\begin{array}{c}\mathrm{Pb} \\
\mathrm{uM}\end{array}$} & \multirow{2}{*}{$\frac{\mathrm{SO}_{4}^{2-}}{\mathrm{mM}}$} & \multirow{2}{*}{$\frac{\mathrm{Zn}^{213}}{\mathrm{uM}}$} \\
\hline & & & & & & $\mathrm{uM}$ & & & & & & & & & \\
\hline \multirow[t]{6}{*}{ CC-PG welle } & \multirow[t]{2}{*}{$6 / 21 / 19$} & Unfiltered & 3.6 & 1.6 & 2.75 & 240 & 0.36 & 0.28 & $<0.09$ & 445 & 33 & 0.21 & 0.09 & NA & 6.4 \\
\hline & & $<0.2 \mu \mathrm{m}$ & & & & 230 & 0.39 & 0.28 & $<0.09$ & 442 & 33.3 & 0.22 & 0.06 & $3.94^{*}$ & 6.51 \\
\hline & \multirow[t]{2}{*}{$7 / 31 / 19^{a}$} & Unfiltered & 3.3 & 3.9 & $>3$ & 58.9 & 0.26 & 0.22 & 0.74 & 37.8 & 37.8 & 0.03 & 0.16 & NA & 15.2 \\
\hline & & $<0.2 \mu \mathrm{m}$ & & & & 50.4 & 0.22 & 0.22 & 0.69 & 30.9 & 38.1 & 0.03 & 0.20 & $2.54^{\star}$ & 15.2 \\
\hline & \multirow[t]{2}{*}{$9 / 21 / 19^{a}$} & Unfiltered & 3.6 & 4.5 & $>3$ & 571 & 0.31 & 1.3 & 0.09 & 414 & 38.7 & 1.1 & 0.53 & NA & 16.2 \\
\hline & & $<0.2 \mu \mathrm{m}$ & & & & 547 & 0.35 & 1.24 & 0.09 & 422 & 37.5 & 1.06 & 0.47 & 3.54 & 15.1 \\
\hline \multirow{6}{*}{$\begin{array}{l}\text { Prospect } \\
\text { Gulch }\end{array}$} & \multirow[t]{2}{*}{$6 / 10 / 20$} & Unfiltered & 3.6 & NA & NA & 95.8 & 0.27 & NA & 3.44 & 88.8 & 4.29 & 0.13 & 0.25 & NA & 10.6 \\
\hline & & $<0.2 \mu \mathrm{m}$ & & & & 94.2 & 0.23 & NA & 3.49 & 87.3 & 4.27 & 0.12 & 0.25 & 0.69 & 10.6 \\
\hline & \multirow{4}{*}{$\begin{array}{l}\text { 2016-2018 (mean of } \\
\text { data collected by the } \\
\text { EPA) }\end{array}$} & Unfiltered & $4.6(1.5)$ & NA & NA & 166 & 0.6 & 5.48 & 2.251 & 523 & 21.1 & 0.24 & 0.28 & 1.29 & 43.3 \\
\hline & & & & & & $252^{d}$ & 1.76 & 23.1 & 6.16 & 1,486 & 55.7 & 0.42 & 0.58 & 1.8 & 96.5 \\
\hline & & $<0.2 \mu \mathrm{m}$ & & NA & NA & 151 & 0.53 & 0.56 & 7.03 & 464 & 19 & 0.25 & 0.27 & NA & 41.2 \\
\hline & & & & & & 237 & 1.81 & 1.58 & 21.8 & 1,345 & 47.1 & 0.39 & 0.6 & & 91.2 \\
\hline \multirow[t]{2}{*}{ Chatt-Fen } & \multirow[t]{2}{*}{ 9/28/19 } & Unfiltered & 4.2 & NA & NA & 20,650 & $<0.11$ & 0.49 & 203 & 8,300 & 32,630 & $<0.02$ & 26.6 & NA & 4,740 \\
\hline & & $<0.2 \mu \mathrm{m}$ & & & & 19,910 & $<0.11$ & 0.48 & 205 & 7,790 & 30,380 & $<0.02$ & 14.2 & 2.10 & 4,560 \\
\hline \multirow{2}{*}{$\begin{array}{l}\text { Artist's Cabin } \\
\text { welle }\end{array}$} & \multirow[t]{2}{*}{$9 / 29 / 19$} & Unfiltered & 6.5 & NA & NA & $<0.04$ & 0.23 & $<0.02$ & $<0.09$ & 0.38 & 0.07 & $<0.02$ & 0.03 & NA & 0.36 \\
\hline & & $<0.2 \mu \mathrm{m}$ & & & & $<0.04$ & $<0.11$ & $<0.02$ & $<0.09$ & 0.28 & 0.03 & $<0.02$ & 0.03 & 1.71 & 0.34 \\
\hline \multirow{7}{*}{$\begin{array}{l}\text { Koehler } \\
\text { Tunnel }\end{array}$} & 9/29/19 & $<0.2 \mu \mathrm{m}$ & 3.2 & NA & NA & 200 & 0.74 & 0.71 & 25.5 & 189 & 205 & 0.78 & 0.23 & $9^{*}$ & 202 \\
\hline & $6 / 11 / 20$ & Unfiltered & 5.5 & NA & NA & 63.1 & 0.86 & NA & 12.4 & 122 & 36 & 0.27 & 0.15 & NA & 54.8 \\
\hline & & $<0.2 \mu \mathrm{m}$ & & & & 36.6 & 0.38 & & 11.8 & 104 & 36.1 & 0.29 & 0.07 & 1.87 & 55.1 \\
\hline & 2016-2017 [mean of & Unfiltered & $4.3(1.3)$ & NA & NA & 189 & 1.33 & NA & 18.7 & 300 & 196 & 0.85 & 0.31 & NA & 176 \\
\hline & $\begin{array}{l}\text { data collected by the } \\
\text { Environmental }\end{array}$ & $-045 \mu \mathrm{m}$ & & & & 96.3 & 0.43 & $N A$ & $\begin{array}{l}9.17 \\
179\end{array}$ & 140 & 120 & 0.59 & 0.06 & 2 & 107 \\
\hline & Protection Agency & $<0.45 \mu \mathrm{m}$ & & & & 100 & 0.02 & $\mathrm{NA}$ & 11.9 & $20<$ & 109 & 0.00 & 0.10 & 2 & 1170 \\
\hline & $(E P A)]^{c}$ & & & & & 733 & 0.13 & & $\begin{array}{l}9.37 \\
0.99\end{array}$ & $7 / 8$ & 122 & 0.57 & 0.72 & 7.3 & 105 \\
\hline Detection limit & & & & & & 0.04 & 0.11 & 0.02 & 0.09 & 0.03 & 0 & 0.02 & 0.02 & 0.04 & 0.46 \\
\hline
\end{tabular}

${ }^{a}$ Corresponds to the date of a hyporheic zone well cluster sampling event.

${ }^{b}$ Average across 42 samples from seeps, springs, and draining mines along Prospect Gulch measured by the EPA in 2016-2018 (Cowie and Roberts, 2020).

${ }^{c}$ Average across three samples collected by the EPA from the Koehler Tunnel discharge on June 28, 2016 and July 11 and September 27, 2017.

${ }^{d}$ Italicized values represent the standard deviation of historical measurements made by the EPA.

e Depth of sample from CC-PG well was $1.1 \mathrm{~m}$; depth for sample from Artist's Cabin well was $10 \mathrm{~m}$.

*Presented as sulfur measured using an inductively coupled plasma-optical emission spectrometer at a wavelength of $181 \mathrm{~nm}$. 


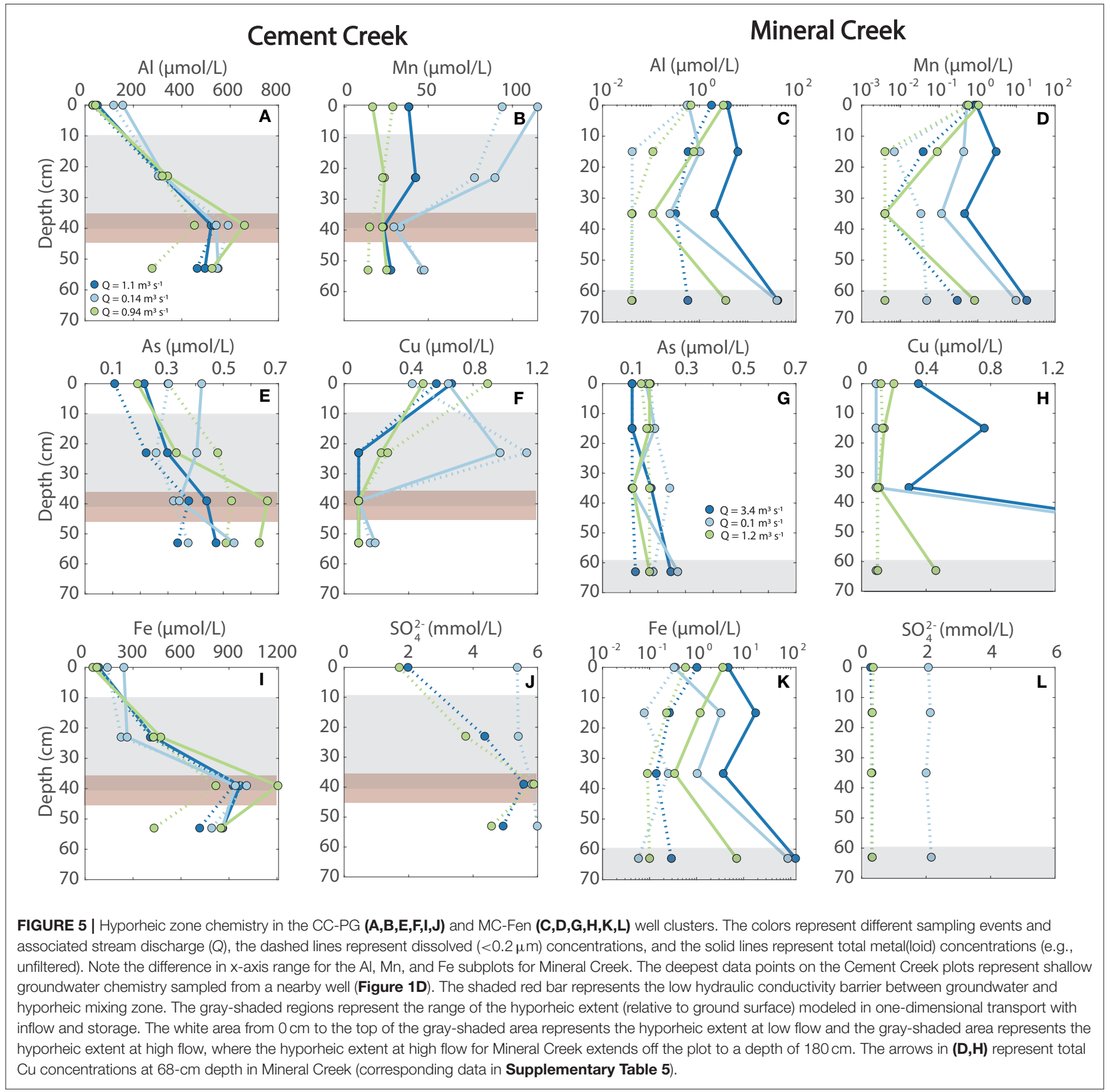

\section{Stream Concentration-Discharge Relationships Linked to Hyporheic Zone Processes}

Seasonal changes in streamflow influenced the hyporheic zone area and mass transfer rates for the Mineral Creek and Cement Creek reaches (as noted in "Section 3.1.4") as well as the subsurface metal(loid) interactions with sediments ("Section metal(loid) behavior in the hyporheic zone at CC-PG and MCFen"). During the period of investigation (February 2019 to May 2020), flow varied from 0.2 to $\sim 7.8 \mathrm{~m}^{3} \mathrm{~s}^{-1}$ at MC-Fen and from 0.2 to $\sim 3.3 \mathrm{~m}^{3} \mathrm{~s}^{-1}$ at CC-PG (Figure 8). Streamflow reached as high as $\sim 7.8 \mathrm{~m}^{3} \mathrm{~s}^{-1}$ at MC-Fen following melt of snowpack $\sim 180 \%$ above that recorded on May 1 of the 2018 water year (according to SNOTEL site \#713) (USDA, 2020). Although the high snowpack followed a period of extreme to exceptional drought that began in January 2018 (NIDIS, 2020), the annual streamflow variability follows a pattern similar to what we observed in 2019, where discharge was greatest following late spring snowmelt and lowest in late summer throughout the winter.

The variability in flow between spring snowmelt, late summer monsoon season, and winter baseflow conditions leads to marked 
TABLE 5 | Saturation indices calculated in PHREEQ-C using stream and hyporheic zone water chemistry.

\begin{tabular}{|c|c|c|c|c|c|c|c|c|c|c|c|c|c|}
\hline Site & $\operatorname{Depth}^{\mathrm{a}}(\mathrm{cm})$ & Flow regime & CB $(\%)^{b}$ & Amorphous Fe-oxide $^{c}$ & Manganite & K-Jarosite & Schwertmannite & Goethite & Alunite & Jurbanite & Al-oxide & Gypsum & Barite \\
\hline \multirow[t]{12}{*}{ Cement Creek } & 0 & High flow 2019 & -0.63 & 1.74 & 1.47 & 3.36 & 15.7 & 6.95 & 0.42 & -0.33 & -3.49 & -1.32 & 0.15 \\
\hline & 23 & & 2.77 & 1.33 & -0.70 & 5.89 & 14.9 & 6.87 & 0.88 & 0.00 & -4.13 & -0.93 & 0.01 \\
\hline & 39 & & 2.36 & 1.48 & -5.99 & 6.54 & 16.7 & 6.88 & 0.11 & 0.11 & -4.65 & -0.82 & -0.43 \\
\hline & 53 & & 4.05 & 1.08 & -0.96 & 5.52 & 13.9 & 6.39 & -1.38 & -0.12 & -5.34 & -0.89 & -0.25 \\
\hline & 0 & High flow 2020 & 3.00 & 2.16 & -4.75 & 3.95 & 18.7 & 7.26 & 0.97 & -0.10 & -3.24 & -1.41 & 0.17 \\
\hline & 23 & & -0.33 & 0.99 & -6.44 & 4.92 & 13.0 & 6.32 & -1.70 & -0.26 & -5.30 & -1.04 & 0.08 \\
\hline & 39 & & -21.8 & 2.06 & -5.53 & 7.28 & 20.4 & 7.44 & 1.64 & 0.38 & -3.84 & -0.89 & 0.20 \\
\hline & 53 & & -17.7 & 1.42 & -6.26 & 5.77 & 15.8 & 6.82 & -0.27 & -0.06 & -4.58 & -0.98 & -0.07 \\
\hline & 0 & Low flow & 0.53 & 0.04 & -0.40 & 2.28 & 6.02 & 5.29 & -4.13 & -0.75 & -6.29 & -0.63 & 0.08 \\
\hline & 23 & & -0.96 & 1.32 & 0.31 & 5.06 & 14.7 & 6.65 & 0.45 & 0.13 & -4.31 & -0.70 & 0.26 \\
\hline & 39 & & -1.41 & 2.00 & 0.03 & 7.33 & 20.3 & 7.24 & 0.99 & 0.39 & -4.33 & -0.76 & -0.22 \\
\hline & 53 & & 3.86 & 1.75 & 0.03 & 6.71 & 18.6 & 6.98 & 0.31 & 0.26 & -4.61 & -0.79 & -0.09 \\
\hline \multirow[t]{12}{*}{ Mineral Creek } & 0 & High flow 2019 & 2.89 & 1.79 & 3.21 & -3.29 & 9.92 & 6.93 & 2.69 & -1.14 & -0.56 & -2.63 & 0.39 \\
\hline & 15 & & -0.52 & 1.49 & 2.46 & -5.06 & 6.55 & 6.63 & 1.46 & -1.84 & -0.69 & -2.51 & 0.34 \\
\hline & 35 & & -8.52 & 1.13 & 1.42 & -6.28 & 3.14 & 6.43 & -0.08 & -2.72 & -0.94 & -2.72 & -0.04 \\
\hline & 63 & & 2.12 & 1.24 & 2.84 & -5.15 & 4.78 & 6.57 & 1.09 & -2.14 & -0.77 & -2.49 & 0.28 \\
\hline & 0 & High flow 2020 & -15.8 & 2.35 & 5.25 & -4.75 & 10.7 & 7.55 & -1.84 & -3.90 & -0.95 & -2.59 & -0.43 \\
\hline & 15 & & 7.68 & 2.01 & 5.22 & -5.49 & 8.53 & 7.10 & -2.06 & -3.69 & -1.27 & -2.44 & -0.37 \\
\hline & 35 & & 0.28 & 1.34 & 2.99 & -7.18 & 3.08 & 6.62 & -3.26 & -4.36 & -1.51 & -2.57 & -0.76 \\
\hline & 63 & & 3.20 & 1.32 & 2.94 & -7.32 & 2.92 & 6.62 & -3.50 & -4.41 & -1.54 & -2.47 & -0.66 \\
\hline & 0 & Low flow & 4.74 & 1.22 & 2.78 & -3.01 & 6.51 & 6.45 & 2.66 & -1.13 & -1.12 & -1.18 & 0.44 \\
\hline & 20 & & -0.67 & 0.88 & 1.58 & -5.27 & 2.63 & 6.10 & -0.83 & -2.57 & -1.88 & -1.20 & 0.51 \\
\hline & 40 & & -9.58 & 1.38 & 2.22 & -3.44 & 6.91 & 6.58 & -0.51 & -2.40 & -1.91 & -1.11 & 0.56 \\
\hline & 70 & & 1.71 & 0.71 & 2.33 & -5.52 & 1.42 & 5.95 & -0.67 & -2.54 & -1.89 & -1.18 & 0.52 \\
\hline
\end{tabular}

${ }^{a}$ Depths represent the mid-point of a $10-\mathrm{cm}$-long screen.

${ }^{b}$ Charge balance.

${ }^{c}$ The chemical formulas for the minerals are as follows: amorphous iron oxide $\left[\mathrm{Fe}(\mathrm{OH})_{3(a)}\right]$, manganite $[\mathrm{MnO}(\mathrm{OH})]$, $\mathrm{K}$-Jarosite $\left[\mathrm{KFe}_{3}^{+3}\left(\mathrm{OH}_{6}\left(\mathrm{SO}_{4}\right)_{2}\right]\right.$, schwertmannite $\left[\mathrm{Fe}{ }_{8} \mathrm{O}_{8}(\mathrm{OH})_{6}\left(\mathrm{SO}_{4}\right) \cdot \mathrm{nH} \mathrm{H}_{2} \mathrm{O}\right]$, goethite $\left[\mathrm{Fe}{ }^{3+} \mathrm{O}(\mathrm{OH})\right]$, alunite $\left[\mathrm{KAl}_{3}\left(\mathrm{SO}_{4}\right)_{2}(\mathrm{OH})_{6}\right]$, jurbanite $\left[\mathrm{AlSO} 4 \cdot 5 \mathrm{H}_{2} \mathrm{O}\right]$, Al-oxide $\left[\mathrm{Al}(\mathrm{OH})_{3}(\mathrm{a})\right]$, gypsum $\left(\mathrm{CaSO}_{4}\right)$, and barite $\left(\mathrm{BaSO}_{4}\right)$. 


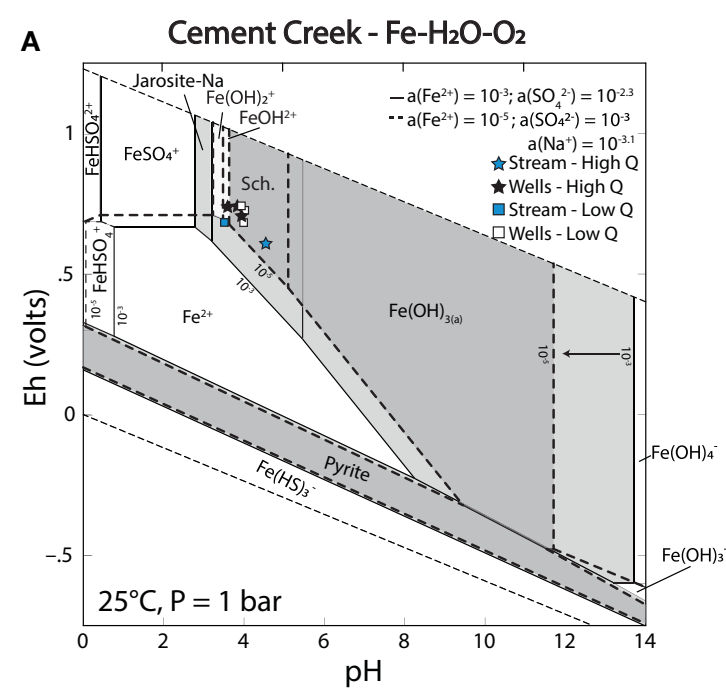

B

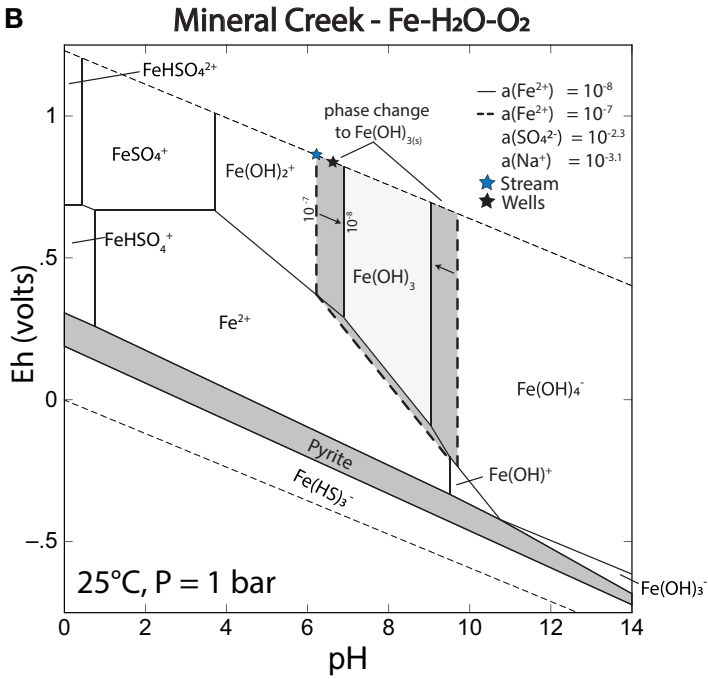

C

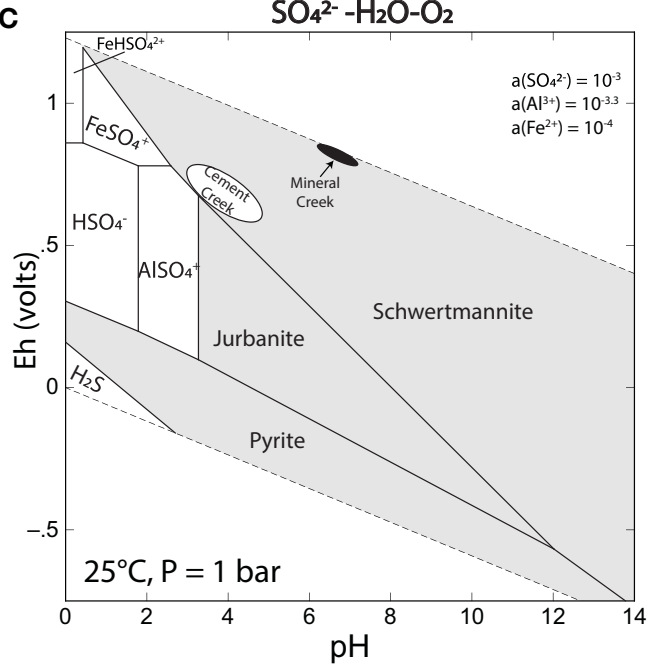

FIGURE 6 | Eh-pH diagrams calculated in Geochemist's Workbench for Fe at (A) Cement Creek and (B) Mineral Creek and for (C) $\mathrm{SO}_{4}^{2-}$ at Mineral Creek

(Continued)
FIGURE 6 | and Cement Creek. Points on the stability diagrams represent the Eh and the $\mathrm{pH}$ of stream and hyporheic well cluster samples collected in 2019. Eh was calculated assuming that $\mathrm{Fe}^{2+} / \mathrm{Fe}^{3+}$ was the dominant redox couple for Cement Creek and assuming that $\mathrm{O}_{2} / \mathrm{O}(0)$ was the dominant redox couple for Mineral Creek. The dashed lines represent contours for diagrams calculated using different molar concentrations of Fe for the range of concentrations measured in the streams and the wells.

differences in seasonal water chemistry in the Bonita Peak Mining District and is reflected in stream CQ relationships. First, the ratio of the load and discharge Gini coefficients $\left(G_{\mathrm{L}}\right.$ / $G_{\mathrm{Q}}$ ) for total and dissolved solutes at MC-Fen was nearly all $1 \pm 0.2$ (except for dissolved $\mathrm{Ca}$ and $\mathrm{Fe}$ ), whereas the $G_{\mathrm{L}} / G_{\mathrm{Q}}$ values for solutes at CC-PG were as low as 0.50.6 for metals such as $\mathrm{As}, \mathrm{Fe}$, and $\mathrm{Al}$. This indicates that load inequality is dominated by discharge inequality at MCFen (i.e., relatively low variability in concentration compared to variability in discharge), whereas the load inequality is greater than the discharge inequality at CC-PG (i.e., high variability in concentration compared to discharge variability). We posit that this difference could be related to the fact that a greater number of draining mines with temporally heterogeneous flow contributions are located upstream of the Cement Creek reach, while the only large draining mine above the Mineral Creek reach is the Koehler Tunnel, which is bulkheaded and had minimal discharge during this study. Second, all solutes in both stream systems were moderately chemodynamic $\left(1.0>\mathrm{CV}_{\mathrm{C}} /\right.$ $\left.\mathrm{CV}_{\mathrm{Q}}>0.2\right)$ to chemodynamic $\left(b> \pm 0.1, \mathrm{CV}_{\mathrm{C}} / \mathrm{CV}_{\mathrm{Q}}>1.0\right)$, and no solutes exhibited a purely chemostatic behavior with low concentration variability $\left(b< \pm 0.1, \mathrm{CV}_{\mathrm{C}} / \mathrm{CV}_{\mathrm{Q}}<0.2\right.$ ). $\mathrm{Cu}$ and $\mathrm{Pb}$ in $\mathrm{CC}-\mathrm{PG}$ and $\mathrm{Mn}$ and $\mathrm{Pb}$ in the $\mathrm{MC}-\mathrm{Fen}$ were the only trace metal(loid)s with power-law slopes for dissolved species less than \pm 0.1 (Table 6), which indicates a chemostatic behavior. While the increase in flow dilutes all other metal concentrations, additional sources of $\mathrm{Cu}, \mathrm{Mn}$, and $\mathrm{Pb}$ that are only accessed at high flow may contribute to the stream channel to counteract dilution.

$\mathrm{CQ}$ trends for major elements (i.e., $\mathrm{Ca}^{2+}, \mathrm{Cl}^{-}, \mathrm{Mg}^{2+}, \mathrm{Na}^{+}$, $\mathrm{SO}_{4}^{2-}$ ) were characterized by negative power law slopes at both CC-PG and MC-Fen, whereas power law slopes were positive for the redox-sensitive metals $\mathrm{Fe}, \mathrm{Al}, \mathrm{Cu}$, and $\mathrm{Mn}$ at MC-Fen (i.e., $b>0.1$, flushing behavior) and negative at CC-PG (i.e., $b<-0.1$, dilution behavior) (Figure 9A and Supplementary Figure 8, Table 6). The difference in trace metal(loid) power law slopes appears to be linked to differences in how metals are exported from the catchment at these two sites. In general for MC-Fen, the power law slopes for total Fe, $\mathrm{Al}, \mathrm{Cu}$, and $\mathrm{Mn}$ concentrations with dissolved, colloidal, and particulate material (unfiltered samples) were higher than the power law slopes of dissolved concentrations (filtered samples, $<0.2 \mu \mathrm{m}$ for our samples and $<0.45 \mu \mathrm{m}$ for historical data) (Figure 9A, Table 6). In contrast, the power law slopes for total and dissolved concentrations of these same metal(loid)s at CCPG were similar (Figure 9A), indicating that metal transport in the dissolved phase is relatively more important at CC-PG 

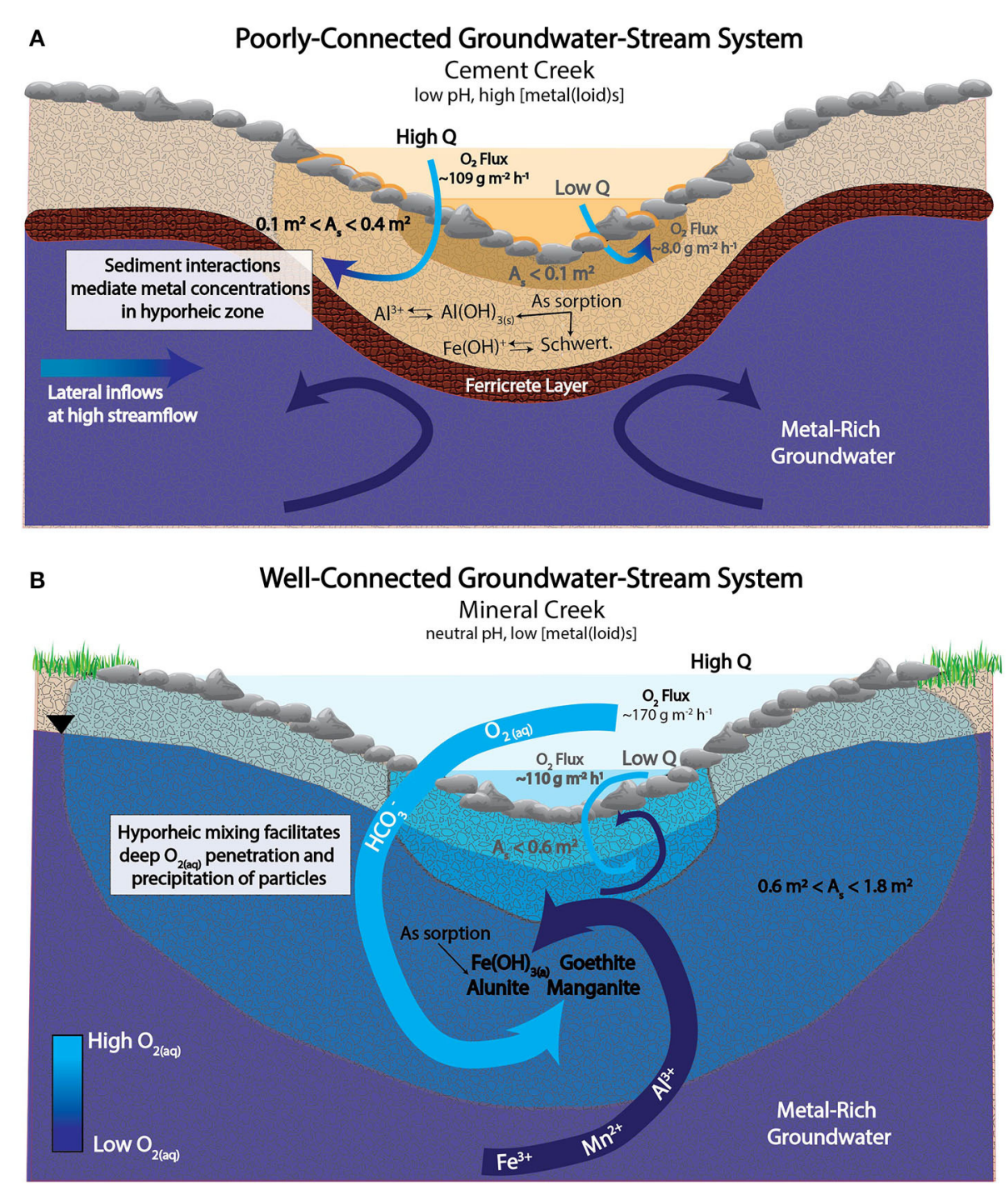

FIGURE 7 | Conceptual model for (A) a poorly connected stream-groundwater system at Cement Creek and (B) a well-connected groundwater-stream system at Mineral Creek. The color of the arrows corresponds to oxygen concentration, where light blue represents oxygenated waters and dark blue represents waters with low dissolved oxygen concentrations. The text in gray denotes low flow, and the text in black denotes high flow oxygen and transient storage conditions. The transient storage areas $\left(A_{s}\right)$ for the poorly connected and well-connected conceptual models are bounded by one-dimensional transport with inflow and storage model estimates. The exchange rate was the same order of magnitude at high and low flow for both systems $\left(\alpha \sim 0.001-0.005 \mathrm{~s}^{-1}\right)$.

compared to MC-Fen. We also observe a separation between $\mathrm{MC}-\mathrm{Fen}$ and CC-PG when comparing the power law slopes to the ratio of dissolved-to-total metal concentrations (Figure 9B). Positive power law slopes were correlated with low concentration ratios of $\mathrm{Al}, \mathrm{Cu}, \mathrm{Fe}$, and $\mathrm{Mn}$ at $\mathrm{MC}-\mathrm{Fen}$, suggesting that the flushing CQ behavior at MC-Fen may be linked to the accumulation of colloids and particulates in the subsurface during baseflow conditions that are accessed and transported to the stream at high flow. A relationship between flushing CQ behavior and concentration ratio was previously observed by Trostle et al. (2016), who found that metals, such as Al, with steeper, positive power law slopes were characterized by a lower ratio of dissolved-to-colloidal form of the metal, and thus these metals were more influenced by colloidal transport. In contrast, a correlation between negative power law slopes and high dissolved-to-total concentration ratios for CC-PG (Figure 9B) indicates that metals are transported primarily in the dissolved phase, and an additional source of colloidal or particulate metals is not contributing metals to the stream under high flow conditions.

Our findings indicate a link between stream-groundwater connectivity in the hyporheic zone (i.e., well-connected vs. poorly connected systems) and stream metal(loid) export at high flow and low flow. In the connected groundwater-stream system of Mineral Creek, colloids and particulates formed as a result of groundwater-surface water mixing in the hyporheic zone. For 
A

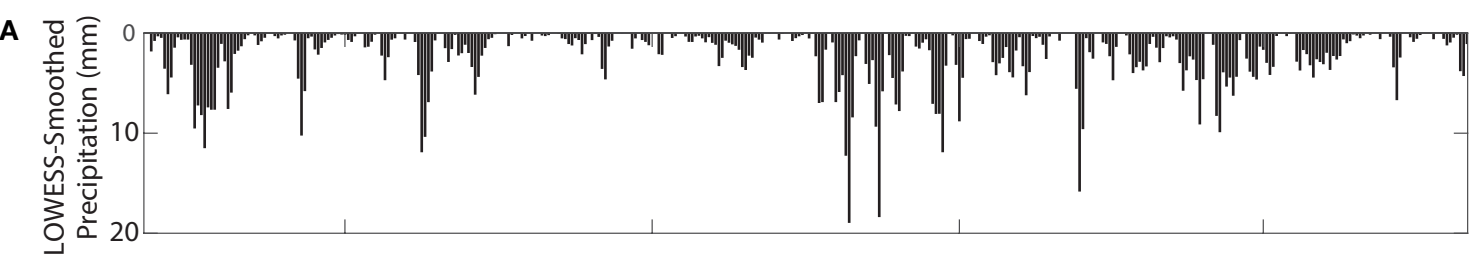

B

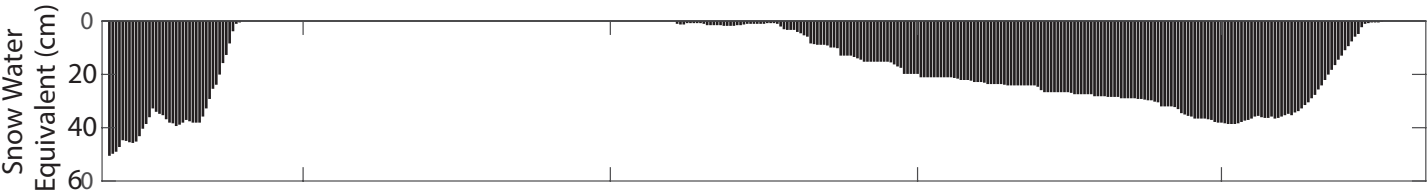

C

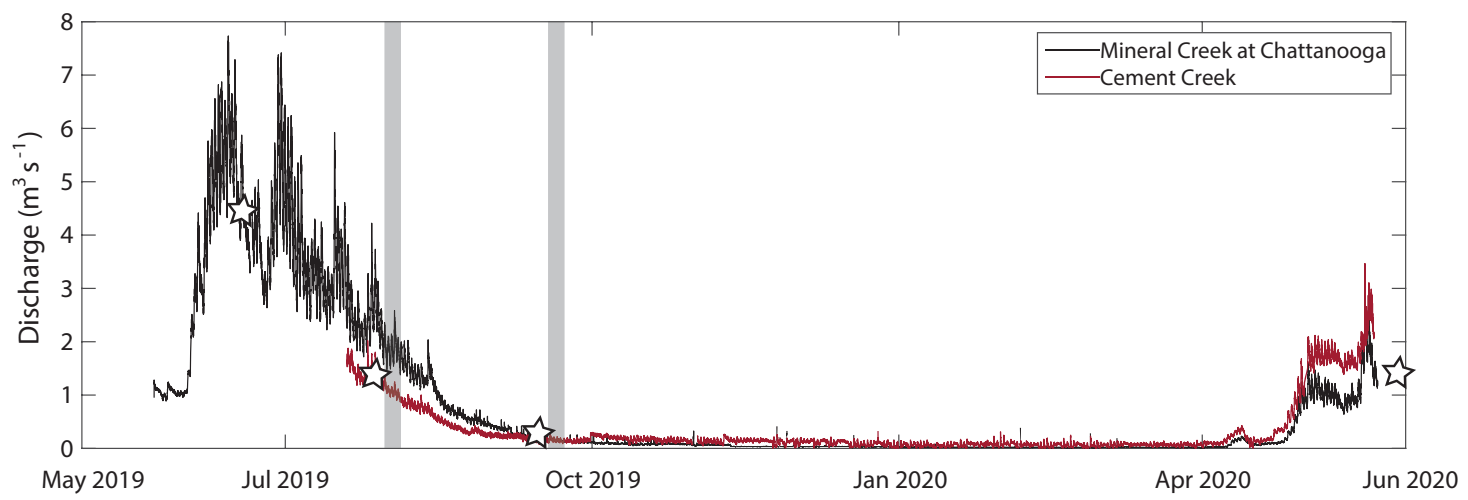

FIGURE 8 | (A) Precipitation from the Gladstone Treatment Plant smoothed using a RLOWESS filter with a filtering window of 3 days, (B) snow water equivalent data from the Mineral Creek SNOTEL site (USDA, 2020), and (C) hydrographs for the stilling wells installed in Mineral Creek near Chattanooga Fen and Cement Creek downstream of Prospect Gulch. The gray-shaded bars represent the period during which tracer tests were completed at high and low flows. The stars represent times of hyporheic zone well sampling.

Mineral Creek near Chattanooga Fen, the increase in hyporheic zone area at high flow compared to low flow (Table 1), the increase in total metal concentrations in the wells at high flow compared to low flow (Figure 5), and the lower concentration ratios of dissolved-to-total metals compared to CC-PG indicate that the flushing $\mathrm{CQ}$ behavior of $\mathrm{Al}, \mathrm{Cu}, \mathrm{Fe}$, and $\mathrm{Mn}$ at high flow is linked to colloid and particle generation in the wellmixed hyporheic zone. Given the lack of stream-groundwater connection (Figure 7A), the small hyporheic area (Table 1), and the difference in dissolved metal concentrations in the stream and the hyporheic zone (Figure 5), we posit that the dilutiondriven trends at CC-PG are not strongly influenced by hyporheic processes. The relatively greater influence of hyporheic processes on whole-stream mass transport at MC-Fen compared to CCPG is further supported by calculations based on mass transfer estimates from the tracer test data. For example, the proportion of median travel time for a solute in the hyporheic zone $\left(F_{\text {med }}\right)$ was lower for CC-PG compared to $\mathrm{MC}-\mathrm{Fen}$, indicating that reactions occurring within the hyporheic zone of CC-PG will have less influence on the metal concentrations in the stream (Table 1).

\section{Potential Implications for Remediation}

The contrast between hyporheic zone processes at these two sites located downstream of acid mine drainage has potential implications for approaches to remediation. The enhanced hyporheic mixing and invariant dissolved metal concentrations with depth at MC-Fen indicate that the initial concentrations of metal(loid)s in the infiltrating stream water are important. Given that the metal(loid) concentrations in the stream are wellmixed with the shallow subsurface, streams such as Mineral Creek would benefit from treatment of the stream itself. Furthermore, dissolved metal contributions to MC-Fen from upwelling groundwater or inflows from metal-rich iron fens are inhibited by precipitation of colloidal and particulate metals in the hyporheic zone. Although these colloidal and particulate metals may be supplied to the stream at high flow (Figure 9A), dissolved metals are naturally attenuated in the subsurface by mixing in the hyporheic zone at MC-Fen.

Dissolved metal(loid)s at depth in Cement Creek were not as sensitive to changes in streamflow as they were at Mineral Creek, and the small hyporheic zone at this site did not naturally remediate metals at CC-PG via surface water-groundwater mixing. The change in metal(loid) concentrations with depth was rather controlled by interactions with subsurface sediments. We posit that high Fe loads from metal-rich mine drainages in the upper portion of the Cement Creek watershed have contributed to ferricrete precipitation and the clogging of hyporheic pore spaces, which limits groundwater-surface water exchange and, in 
TABLE 6 | Power law slopes (b) for concentration-discharge relationships for Mineral Creek and Cement Creek at two locations, including the standard error of the slope ( $s_{b}$ ), coefficients of variation (CV), and Gin coefficients for concentration $\left(G_{\llcorner}\right)$normalized to the Gini coefficient for discharge $\left(G_{Q}\right)$.

\begin{tabular}{|c|c|c|c|c|c|c|c|c|c|c|c|c|c|}
\hline \multirow[t]{2}{*}{ Filter size } & \multirow[t]{2}{*}{ Solute } & \multicolumn{6}{|c|}{ Cement Creek-Prospect Gulch } & \multicolumn{6}{|c|}{ Mineral Creek-Chattanooga Fen } \\
\hline & & $n^{\mathrm{a}}$ & $b^{\mathrm{b}}$ & $s_{\mathrm{b}}$ & $\mathrm{CV}_{\mathrm{c}} / \mathrm{CV}_{\mathrm{Q}}^{\mathrm{c}}$ & $G_{\mathrm{L}} / G_{Q}^{\mathrm{d}}$ & $R^{2}$ & $n$ & $b$ & $s_{\mathrm{b}}$ & $\mathrm{Cv}_{\mathrm{c}} / \mathrm{Cv}_{\mathrm{Q}}$ & $G_{L} / G_{Q}$ & $R^{2}$ \\
\hline \multirow[t]{12}{*}{ Filtered $(<0.2$ and $<0.45 \mu \mathrm{m})$} & As & 18 & -0.6 & 0.19 & 0.53 & 0.5 & 0.4 & 10 & -0.33 & 0.19 & 0.70 & 1.2 & 0.1 \\
\hline & $\mathrm{Al}$ & 18 & -0.9 & - & 0.75 & 0.9 & 0.7 & 10 & 0.31 & 0.2 & 0.71 & 1.1 & 0.4 \\
\hline & $\mathrm{Cu}$ & 18 & 0.06 & 0.17 & 0.55 & 1.2 & 0.0 & 10 & 0.22 & 0.11 & 0.46 & 1.2 & 0.4 \\
\hline & $\mathrm{Fe}$ & 18 & -0.9 & - & 0.75 & 0.5 & 0.7 & 10 & 0.53 & 0.32 & 1.03 & 1.3 & 0.4 \\
\hline & $\mathrm{Mn}$ & 18 & -0.4 & 0.37 & 0.92 & 0.9 & 0.2 & 10 & 0.10 & 0.15 & 0.51 & 1.0 & 0.1 \\
\hline & $\mathrm{Pb}$ & 17 & 0.07 & 0.15 & 0.53 & 0.7 & 0.0 & 10 & -0.08 & 0.11 & 0.32 & 0.9 & 0.1 \\
\hline & $\mathrm{SO}_{4}$ & 17 & -0.6 & 0.14 & 0.49 & 0.6 & 0.7 & 8 & -0.64 & 0.17 & 1.03 & 0.9 & 0.7 \\
\hline & $\mathrm{Zn}$ & 18 & -0.3 & 0.3 & 0.78 & 0.7 & 0.3 & 10 & -0.18 & 0.11 & 0.44 & 0.9 & 0.2 \\
\hline & $\mathrm{Ca}$ & 18 & -0.3 & 0.31 & 0.79 & 0.9 & 0.2 & 10 & -0.60 & 0.11 & 0.85 & 0.6 & 0.7 \\
\hline & $\mathrm{Cl}$ & 15 & -0.6 & 0.43 & 0.84 & 0.9 & 0.2 & 8 & -0.22 & 0.12 & 0.55 & 1.0 & 0.3 \\
\hline & $\mathrm{Mg}$ & 18 & -0.4 & 0.14 & 0.43 & 0.7 & 0.6 & 10 & -0.28 & 0.06 & 0.42 & 0.9 & 0.7 \\
\hline & $\mathrm{Si}$ & 18 & -0.5 & 0.26 & 0.71 & 0.7 & 0.2 & 10 & -0.13 & 0.15 & 0.55 & 1.0 & 0.1 \\
\hline \multirow[t]{10}{*}{ Unfiltered } & As & 18 & -0.4 & 0.12 & 0.42 & 0.8 & 0.5 & 10 & -0.28 & 0.14 & 0.60 & 1.0 & 0.3 \\
\hline & $\mathrm{Al}$ & 18 & -0.9 & - & 0.79 & 0.6 & 0.7 & 10 & 0.55 & 0.22 & 0.76 & 1.1 & 0.4 \\
\hline & $\mathrm{Cu}$ & 18 & 0.06 & 0.16 & 0.50 & 1.1 & 0.0 & 10 & 0.34 & 0.15 & 0.57 & 1.2 & 0.5 \\
\hline & $\mathrm{Fe}$ & 18 & -0.8 & - & 0.72 & 0.6 & 0.7 & 10 & 0.82 & 0.22 & 0.79 & 1.1 & 0.6 \\
\hline & $\mathrm{Mn}$ & 18 & -0.4 & 0.37 & 0.90 & 0.9 & 0.1 & 10 & 0.21 & 0.14 & 0.48 & 1.0 & 0.2 \\
\hline & $\mathrm{Pb}$ & 17 & 0.28 & 0.26 & 0.63 & 1.3 & 0.2 & 10 & 0.19 & 0.2 & 0.70 & 1.1 & 0.1 \\
\hline & $\mathrm{Zn}$ & 18 & -0.3 & 0.29 & 0.75 & 0.8 & 0.3 & 10 & -0.10 & 0.12 & 0.43 & 0.9 & 0.1 \\
\hline & $\mathrm{Ca}$ & 18 & -0.4 & 0.3 & 0.76 & 0.8 & 0.2 & 9 & -0.55 & & 0.79 & 0.8 & 0.7 \\
\hline & $\mathrm{Mg}$ & 18 & -0.5 & 0.11 & 0.40 & 0.6 & 0.7 & 9 & -0.23 & 0.07 & 0.36 & 1.0 & 0.7 \\
\hline & $\mathrm{Si}$ & 18 & -0.6 & - & 0.72 & 0.6 & 0.2 & 9 & -0.15 & 0.12 & 0.44 & 1.0 & 0.2 \\
\hline
\end{tabular}

aNumber of observations.

${ }^{b}$ Power law slopes, $s_{b}$, and $R^{2}$ determined with MATLAB nlmfit function.

${ }^{\circ}$ Coefficient of variation calculated as the standard deviation divided by the mean of all samples.

${ }^{d}$ Gini coefficients calculated in R using "ineq" package. 

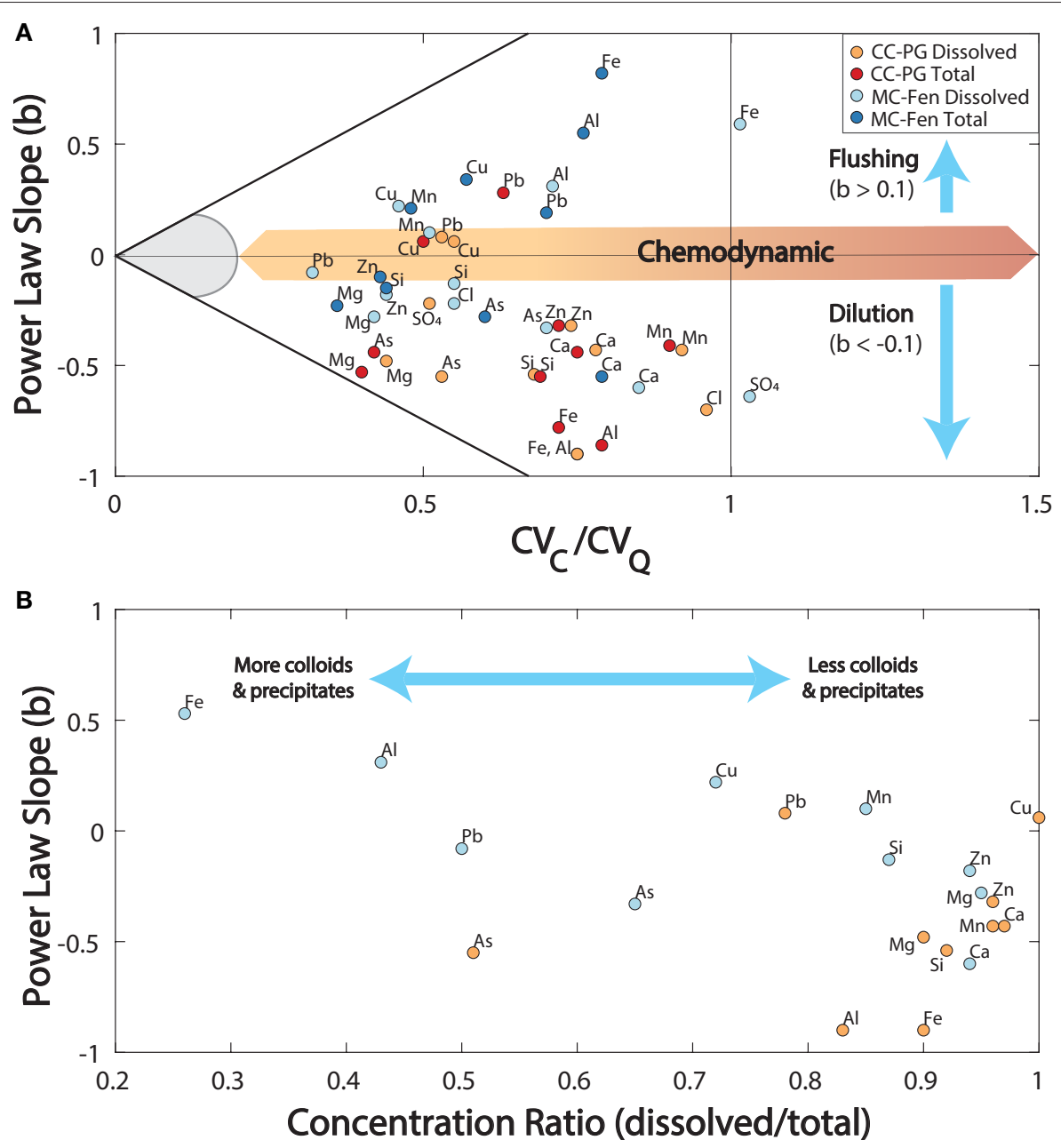

FIGURE 9 | (A) $\mathrm{CV}_{\mathrm{C}} / \mathrm{CV}_{\mathrm{Q}}$ and power law slopes for redox-sensitive metals and major elements for the tracer study reaches and (B) power law slopes vs. the ratio of dissolved $(<0.2$ or $<0.45 \mu \mathrm{m})$ and total (unfiltered) samples.

turn, concentrates toxic metal(loid)s in the shallow subsurface. We suggest that subsurface reactive barriers or removal of contaminated sediments will restore the ecosystem services provided by the hyporheic zone and help remove naturally occurring metals discharging from metal-rich groundwater to the stream, as well as anthropogenic metals infiltrating from the stream into the hyporheic zone. However, direct restoration of hyporheic sediments will not be effective unless iron loading from upstream draining mines is also reduced. Flow reduction from draining mines will decrease iron contributions to Cement Creek, which may, reduce ferricrete precipitation and clogging of the hyporheic zone. Even though $\mathrm{Fe}$ is not considered as toxic a metal as $\mathrm{As}, \mathrm{Al}, \mathrm{Cd}$, or $\mathrm{Zn}$, which are the primary foci of remediation efforts in the Bonita Peak Mining District, our study suggests that treatment of $\mathrm{Fe}$ is equally important given the effect it has on the physical structure of the hyporheic zone at Cement Creek.

The transient storage model OTIS, in combination with geochemical data from the hyporheic zone well clusters, highlighted distinct differences in metal fate and transport at Mineral and Cement Creeks, yet the parameters estimated in OTIS do not necessarily capture the full complexity of physical and chemical processes occurring in the hyporheic zone, particularly for highly advective streams such as Mineral Creek. Future work could implement multi-rate mass transfer models (e.g., Fang et al., 2020), physical and advective models that consider channel morphology (e.g., Cardenas and Wilson, 2007; Marzadri et al., 2012, 2013; Boano et al., 2014), or coupled reactive transport-hyporheic models (Zarnetske et al., 2012; Trauth et al., 2014) to understand finer-scale processes affecting the metal dynamics in poorly connected and well-connected stream-groundwater systems.

\section{CONCLUSIONS}

The goal of this study was to determine how the hyporheic zone influences metal export in streams impacted by acid mine drainage. By comparing the hydrogeochemical properties of 
two streams in the Animas River headwaters of southwestern Colorado, we discovered differences in how the form and function of the hyporheic zone influence the concentrations of redox-sensitive metal(loid)s in mine-impacted and acid rock drainage streams. The key findings highlighted in this study include:

(i) The stream system with low average linear velocities and less permeable sediments (Cement Creek) was characterized by relatively small hyporheic zone areas at low flow and high flow, whereas the system with high average linear velocities and more permeable sediments (Mineral Creek) was characterized by relatively large hyporheic areas that were sensitive to changes in stream discharge.

(ii) Mass transfer rates from OTIS modeling and conservative element behavior in the well clusters reflected the degree of connection between the stream and the groundwater in the hyporheic zone. Mineral Creek represented a wellconnected groundwater-stream system, facilitated by a large hyporheic storage area and invariable conservative element concentrations as a function of depth. Cement Creek represented a poorly connected groundwaterstream system, where hyporheic area and low hydraulic conductivities were limited by ferricrete precipitation. Conservative element concentrations were insensitive to changes in streamflow in the deep subsurface compared to the stream and shallow subsurface.

(iii) Saturation indices and $\mathrm{Eh}-\mathrm{pH}$ diagrams indicated that $\mathrm{Al}$ and $\mathrm{Fe}$ were buffered by mineral equilibria at Cement Creek, and the sediment-dissolved metal(loid) interactions in this poorly connected system were a more important regulator of metal concentrations than physical mixing of water within the hyporheic zone. Colloid and particulate precipitation in Mineral Creek were due to the extensive mixing of oxygen-rich stream water and metal-rich groundwater in the hyporheic zone.

(iv) Differences in groundwater-stream connectivity at these two sites impacted stream metal(loid) export, as highlighted by concentration-discharge relationships. Positive power law slopes were linked to colloidal and particulate metal formation in the hyporheic zone at Mineral Creek. The poorly connected groundwater-stream system of Cement Creek was less important for overall stream metal(loid) export, and negative chemodynamic power law slopes reflect the influence of hillslope flow contributions on CQ rather than in-stream processes.

These differences in hyporheic zone characteristics and groundwater-stream connectivity can inform localized approaches to treatment. Even though Mineral Creek was downstream and adjacent to metal-rich sources (i.e., a mine drainage and iron fen), the neutral $\mathrm{pH}$ and low metal concentrations in the stream reflected the $\mathrm{pH}$ and the metal concentrations in the hyporheic zone. Thus, streams such as this with geochemically well-mixed hyporheic zones already benefit from the natural attenuation of metals in the subsurface, such that remediation efforts could focus on stream water treatment. The small hyporheic zone and poorly connected groundwater-stream system at Cement Creek did not attenuate metals in the subsurface and did not appear to influence stream metal(loid) export. Metals such as $\mathrm{Fe}$ and $\mathrm{Al}$ concentrated in the subsurface as a result of interactions with metal-laden sediments. Poorly connected systems such as these would benefit from remediation of the shallow subsurface and removal or treatment of sediments.

\section{DATA AVAILABILITY STATEMENT}

The original contributions presented in the study are included in the article/Supplementary Materials, further inquiries can be directed to the corresponding author/s.

\section{AUTHOR CONTRIBUTIONS}

$\mathrm{BH}$ designed, led the field experiments, data collection, laboratory analyses, data processing/modeling, and the writing of this manuscript. RC contributed to site selection and field sampling. RC, AN-S, and KS contributed to the editing and data analysis within this manuscript. AN-S, KS, and BH acquired funding to carry out this project. All authors contributed to the article and approved the submitted version.

\section{FUNDING}

Financial support for this study was provided by the National Science Foundation Earth Sciences Postdoctoral Fellowship program [grant no. 1806718]. Any opinions, findings, and conclusions or recommendations expressed in this material are those of the authors and do not necessarily reflect the views of the National Science Foundation.

\section{ACKNOWLEDGMENTS}

We would like to acknowledge the extensive help with field work provided by Kendall Wnuk, Jackie Randell, Ariel Rickel, Sawyer McFadden, and Luke Jacobsen at the Colorado School of Mines, Nate Rock at Mountain Studies Institute, and Stefan Klingler from the University of Tubingen. Additional thanks go to Rob Runkel with the US Geological Survey and Peter Butler with the Animas River Stakeholders Group for an introduction to the field area and help in identifying field sites. We would like to acknowledge and thank Lisa Merrill and Andrew Breibart at the Bureau of Land Management, as well as Benerito Martinez and Lewis Sovocool at the US Forest Service, for help with the permitting process and for access to the site.

\section{SUPPLEMENTARY MATERIAL}

The Supplementary Material for this article can be found online at: https://www.frontiersin.org/articles/10.3389/frwa. 2020.600409/full\#supplementary-material

Streamflow data for Mineral and Cement Creek referenced in this paper can be found on Hydroshare: https://doi.org/10.4211/ hs.c9ef6ecde25640d4bd4c7a9c50575016. 


\section{REFERENCES}

Alpers, C. N., Nordstrom, D. K., Verosub, K. L., and Helm-Clark, C. (2007). Paleomagnetic determination of pre-mining metal-flux rates at the Iron Mountain Superfund Site, Northern California. Eos Trans. Jt. Assem. Suppl. Abstr. 88, AGU-10194685.

Anthony, J. W., and McLean, W. J. (1976). Jurbanite, a new post-mine aluminum sulfate mineral from San Manuel, Arizona. Am. Min. 61, 1-4.

Ball, J. W., and Nordstrom, D. K. (1987). User's Manual for WATEQ4F, With Revised Thermodynamic Data Base and Text Cases for Calculating Speciation of Major, Trace, and Redox Elements in Natural Waters. U.S. Geological Survey. doi: 10.3133 /ofr91183

Bencala, K. E. (2011). "Stream-groundwater interactions," in Treatise on Water Science, ed. P. Wilderer (Oxford: Academic Press), 537-546. doi: 10.1016/B978-0-444-53199-5.00115-9

Benner, S. G., Smart, E. W., and Moore, J. N. (1995). Metal behavior during surfacegroundwater interaction, silver bow Creek, Montana. Environ. Sci. Technol. 29, 1789-1795. doi: 10.1021/es00007a015

Bigham, J. M., Schwertmann, U., Carlson, L., and Murad, E. (1990). A poorly crystallized oxyhydroxysulfate of iron formed by bacterial oxidation of $\mathrm{Fe}(\mathrm{II})$ in acid mine waters. Geochim. Cosmochim. Acta 54, 2743-2758. doi: 10.1016/0016-7037(90)90009-A

Boano, F., Harvey, J. W., Marion, A., Packman, A. I., Revelli, R., Ridolfi, L., et al. (2014). Hyporheic flow and transport processes: mechanisms, models, and biogeochemical implications. Rev. Geophys. 52, 603-679. doi: $10.1002 / 2012 R G 000417$

Borch, T., Kretzschmar, R., Skappler, A., Van Cappellen, P., Ginder-Vogel, M., Voegelin, A., et al. (2010). Biogeochemical redox processes and their impact on contaminant dynamics. Environ. Sci. Technol. 44, 15-23. doi: $10.1021 / \mathrm{es} 9026248$

Bouwer, H., and Rice, R. C. (1976). A slug test for determining hydraulic conductivity of unconfined aquifers with completely or partially penetrating wells. Water Resour. Res. 12, 423-428. doi: 10.1029/WR012i003p00423

Bove, D. J., Mast, M., Dalton, J., Wright, W., and Yager, D. (2007). "Chapter E3: Major styles of mineralization and hydrothermal alteration and related solid- and aqueous-phase geochemical signatures," in US Geological Survey Professional Paper 1651, vol. 1, eds S. E. Church, P. von Guerard and S. E. Finger (Reston, VA).

Brown, B. V., Valett, H. M., and Schreiber, M. E. (2007). Arsenic transport in groundwater, surface water, and the hyporheic zone of a mine-influenced stream-aquifer system. Water Resour. Res. 43, 1-14. doi: 10.1029/2006WR005687

Bryant, S. R., Sawyer, A. H., Briggs, M. A., Saup, C. M., Nelson, A. R., Wilkins, M. J., et al. (2020). Seasonal manganese transport in the hyporheic zone of a snowmelt-dominated river (East River, Colorado, USA). Hydrogeol. J. 28, 1323-1341. doi: 10.1007/s10040-020-02146-6

Buxton, H. T., Nimich, D. A., von Guerard, P., Church, S. E., Frazier, A., Gray, J. R., et al. (1997). A science-based, watershed strategy to support effective remediation of abandoned mine lands. in Proceedings of the Fourth International Conference on Acid Rock Drainage (Vancouver, BC), 1869-1880.

Cardenas, M. B., and Wilson, J. L. (2007). Exchange across a sedimentwater interface with ambient groundwater discharge. J. Hydrol. 346, 69-80. doi: 10.1016/j.jhydrol.2007.08.019

Chimner, R. A., Lemly, J. M., and Cooper, D. J. (2010). Mountain fen distribution, types and restoration priorities, San Juan Mountains, Colorado, USA. Wetlands 30, 763-771. doi: 10.1007/s13157-010-0039-5

Clesceri, L. S., Greenberg, A., and Eaton, A. (1999). Standards for the Examination of Water and Wastewater, 20th ed. Washington, DC: American Public Health Association.

Cowie, R., and Roberts, S. (2020). Bonita Peak Mining District 2016-2018 Seeps, Springs, and Draining Mines Characterization Report. Denver, CO: U.S. Environmental Protection Agency, 1-481.

Danczak, R. E., Sawyer, A. H., Williams, K. H., Stegen, J. C., Hobson, C., and Wilkins, M. J. (2016). Seasonal hyporheic dynamics control coupled microbiology and geochemistry in colorado river sediments. J. Geophys. Res. Biogeosci. 121, 2976-2987. doi: 10.1002/2016JG003527

Day, T. J. (1977). Field procedures and evaluation of a slug dilution gauging method in mountain streams. J. Hydrol. 16, 113-133.
Doherty, J. (2010) PEST, Model-Independent Parameter Estimation-User Manual. 5th Edn. Brisbane: Watermark Numerical Computing.

Fang, Y., Chen, X., Velez, J. G., Zhang, X., Duan, Z., Hammond, G. E., et al. (2020). A multirate mass transfer model to represent the interaction of multicomponent biogeochemical processes between surface water and hyporheic zones (SWAT-MRMT-R 1.0). Geosci. Model Dev. 13, 3553-3569. doi: 10.5194/gmd-13-3553-2020

Fattorini, D., Notti, A., Di Mento, R., Cicero, A. M., Gabellini, M., Russo, A., et al. (2008). Seasonal, spatial and inter-annual variations of trace metals in mussels from the adriatic sea: a regional gradient for arsenic and implications for monitoring the impact of off-shore activities. Chemosphere 72, 1524-1533. doi: 10.1016/j.chemosphere.2008.04.071

Feris, K. P., Ramsey, P. W., Frazar, C., Rillig, M., Moore, J. N., Gannon, J. E., et al. (2004). Seasonal dynamics of shallow-hyporheic-zone microbial community structure along a heavy-metal contamination gradient. Appl. Environ. Microbiol. 70, 2323-2331. doi: 10.1128/AEM.70.4.2323-2331.2004

Findlay, S. E. G., Sinsabaugh, R. L., Sobczak, W. V., and Hoostal, M. (2003). Metabolic and structural response of hyporheic microbial communities to variations in supply of dissolved organic matter. Limnol. Oceanogr. 48, 1608-1617. doi: 10.4319/lo.2003.48.4.1608

Fischer, H., Kloep, F., Wilzcek, S., and Pusch, M. T. (2005). A river's liver: microbial processes within the hyporheic zone of a large lowland river. Biogeochemistry 76, 349-371. doi: 10.1007/s10533-005-6896-y

Gall, H. E., Park, J., Harman, C. J., Jawitz, J. W., and Rao, P. S. C. (2013). Landscape filtering of hydrologic and biogeochemical responses in managed catchments. Landsc. Ecol. 28, 651-664. doi: 10.1007/s10980-012-9829-x

Gandy, C. J., Smith, J. W. N., and Jarvis, A. P. (2007). Attenuation of miningderived pollutants in the hyporheic zone: a review. Sci. Total Environ. 373, 435-446. doi: 10.1016/j.scitotenv.2006.11.004

Godsey, S. E., Kirchner, J. W., and Clow, D. W. (2009). Concentration-discharge relationships reflect chemostatic characteristics of US catchments. Hydrol. Process. 23, 1844-1864. doi: 10.1002/hyp.7315

Guerard, P., Von Church, S. E., Yager, D. B., and Besser, J. M. (2004). "Chapter B: The animas river watershed, San Juan County, Colorado," in US Geological Survey Professional Paper 1651, vol. 1, eds S. E. Church, P. von Guerard and S. E. Finger (San Juan County, Colorado).

Harvey, J. W., and Fuller, C. C. (1998). Effect of enhanced manganese oxidation in the hyporheic zone on basin-scale geochemical mass balance. Water Resour. Res. 34, 623-636. doi: 10.1029/97WR03606

Hatch, C. E., Fisher, A. T., Revenaugh, J. S., Constantz, J., and Ruehl, C. (2006). Quantifying surface water-groundwater interactions using time series analysis of streambed thermal records: method development. Water Resour. Res. 42, 1-14. doi: 10.1029/2005WR004787

Hatch, C. E., Fisher, A. T., Ruehl, C. R., and Stemler, G. (2010). Spatial and temporal variations in streambed hydraulic conductivity quantified with time-series thermal methods. J. Hydrol. 389, 276-288. doi: 10.1016/j.jhydrol.2010.05.046

Hester, E. T., and Doyle, M. W. (2008). In-stream geomorphic structures as drivers of hyporheic exchange. Water Resour. Res. 44:5810. doi: 10.1029/2006WR005810

Hoagland, B., Russo, T. A., Gu, X., Hill, L., Kaye, J., Forsythe, B., et al. (2017). Hyporheic zone influences on concentration-discharge relationships in a headwater sandstone stream. Water Resour. Res. 53, 4643-4667. doi: 10.1002/2016WR019717

Horton, J., and San Juan, C. A. (2020). Prospect- and mine-related features from U.S. Geological Survey 7.5- and 15-minute topographic quadrangle maps of the United States. U.S. Geol. Surv. data release ver. 5.0. doi: 10.5066/ F78W3CHG

Howard, A. G., Comber, S. D. W., Kifle, D., Antai, E. E., and Purdie, D. A. (1995). Arsenic speciation and seasonal changes in nutrient availability and microplankton abundance in southampton water, U.K. Estuar. Coast. Shelf Sci. 40, 435-450. doi: 10.1006/ecss. 1995.0030

Hudson-Edwards, K. (2016). Tackling mine wastes. Science 352, 288-290. doi: $10.1126 /$ science.aaf3354

Jawitz, J. W., and Mitchell, J. (2011). Temporal inequality in catchment discharge and solute export. Water Resour. Res. 47, 1-16. doi: 10.1029/2010WR010197

Johnson, B. R. H., Wirt, L., Manning, A. H., Leib, K. J., Fey, D. L., Douglas, B., et al. (2007). In cooperation with the bureau of land management geochemistry of surface and ground water in Cement Creek from Gladstone to Georgia Gulch 
and in Prospect Gulch. San Juan County, Colorado: U.S. Geological Survey. doi: 10.3133/ofr20071004

Kasahara, T., and Hill, A. R. (2007). Lateral hyporheic zone chemistry in an artificially constructed gravel bar and a re-meandered stream channel, Southern Ontario, Canada. J. Am. Water Resour. Assoc. 43, 1257-1269. doi: 10.1111/j.1752-1688.2007.00108.x

Marzadri, A., Tonina, D., and Bellin, A. (2012). Morphodynamic controls on redox conditions and on nitrogen dynamics within the hyporheic zone: application to gravel bed rivers with alternate-bar morphology. J. Geophys. Res. Biogeosci. 117, 1-14. doi: 10.1029/2012JG001966

Marzadri, A., Tonina, D., and Bellin, A. (2013). Effects of stream morphodynamics on hyporheic zone thermal regime. Water Resour. Res. 49, 2287-2302. doi: $10.1002 /$ wrcr.20199

Miller, M. P., McKnight, D. M., Cory, R. M., Williams, M. W., and Runkel, R. L. (2006). Hyporheic exchange and fulvic acid redox reactions in an alpine stream/wetland ecosystem, Colorado front range. Environ. Sci. Technol. 40, 5943-5949. doi: 10.1021/es060635j

Morrice, J. A., Valett, H. M., Dahm, C. N., and Campana, M. E. (1997). Alluvial characteristics, groundwater-surface water exchange and hydrological retention in headwater streams. Hydrol. Process. 11, 253-267. doi: 10.1002/(SICI) 1099-1085(19970315)11:3<253::AID-HYP439>3.0.CO;2-J

Musolff, A., Schmidt, C., Selle, B., and Fleckenstein, J. H. (2015). Catchment controls on solute export. Adv. Water Resour. 86, 133-146. doi: 10.1016/j.advwatres.2015.09.026

Nagorski, S. A., and Moore, J. N. (1999). Arsenic mobilization in the hyporheic zone of a stream. Hydrogeochem. Water Chem. 35, 3441-3450. doi: 10.1029/1999WR900204

Nagorski, S. A., Moore, J. N., McKinnon, T. E., and Smith, D. B. (2003). Geochemical response to variable streamflow conditions in contaminated and uncontaminated streams. Water Resour. Res. 39:1247. doi: 10.1029/2001WR001247

Nelson, A. R., Sawyer, A. H., Gabor, R. S., Saup, C. M., Bryant, S. R., Harris, K. D., et al. (2019). Heterogeneity in hyporheic flow, pore water chemistry, and microbial community composition in an alpine streambed. J. Geophys. Res. Biogeosci. 124, 3465-3478. doi: 10.1029/2019JG005226

NIDIS (2020). North American Drought Monitor (NADM). Natl. Integr. Drought Inf. Syst. Available online at: https://www.drought.gov/drought/data-gallery/ north-american-drought-monitor-nadm (accessed April 1, 2020).

Nordstrom, D. K. (2011). Mine waters: acidic to circmneutral. Elements 7, 393-398. doi: 10.2113/gselements.7.6.393

Parkhurst, D. L., and Appelo, C. A. J. (2013). PHREEQC (Version 3)-A computer program for speciation, batch-reaction, one-dimensional transport, and inverse geochemical calculations. Model. Tech. B 6:497. doi: 10.3133/tm6A43

Rodriguez-Freire, L., Avasarala, S., Ali, A. M. S., Agnew, D., Hoover, J. H., Artyushkova, K., et al. (2016). Post gold king mine spill investigation of metal stability in water and sediments of the animas river watershed. Environ. Sci. Technol. 50, 11539-11548. doi: 10.1021/acs.est.6b03092

Runkel, R. (1998). One-Dimensional Transport with Inflow and Storage: A Solute Transport Model for Streams and Rivers. Denver, CO: U.S. Geological Survey.

Runkel, R. L. (2002). A new metric for determining the importance of transient storage. J. North Am. Benthol. Soc. 21, 529-543. doi: 10.2307/ 1468428

Runkel, R. L., Bencala, K. E., Kimball, B. A., Walton-day, K., and Verplanck, P. L. (2009a). A comparison of pre- and post-remediation water quality. Hydrol. Process. 23, 3319-3333. doi: 10.1002/hyp.7427

Runkel, R. L., and Kimball, B. A. (2002). Evaluating remedial alternatives for an acid mine drainage stream: application of a reactive transport model. Environ. Sci. Technol. 36, 1093-1101. doi: 10.1021/es0109794

Runkel, R. L., Kimball, B. R., Steiger, J. I., and Walton-day, K. (2009b). Geochemical data for upper Mineral Creek, Colorado, under existing ambient conditions and during an experimental $\mathrm{pH}$ modification, August 2005. U. S. Geol. Surv. Data Ser. 442:41. doi: 10.3133/ds442

Saup, C. M., Bryant, S. R., Nelson, A. R., Harris, K. D., Sawyer, A. H., Christensen, J. N., et al. (2019). Hyporheic zone microbiome assembly is linked to dynamic water mixing patterns in snowmelt-dominated headwater catchments. J. Geophys. Res. Biogeosci. 124, 3269-3280. doi: 10.1029/2019JG 005189
Saup, C. M., Williams, K. H., Rodríguez-Freire, L., Cerrato, J. M., Johnston, M. D., and Wilkins, M. J. (2017). Anoxia stimulates microbially catalyzed metal release from animas river sediments. Environ. Sci. Process. Impacts 19, 578-585. doi: 10.1039/C7EM00036G

Schwertmann, U. (1991). Solubility and dissolution of iron oxides. Plant Soil 130, 1-25. doi: 10.1007/BF00011851

Sherrell, R. M., and Ross, J. M. (1999). Temporal variability of trace metals in New Jersey Pinelands streams: relationships to discharge and $\mathrm{pH}$. Geochim. Cosmochim. Acta 63, 3321-3336. doi: 10.1016/S0016-7037(99)00 254-9

Singley, J. G., Wlostowski, A. N., Bergstrom, A. J., Sokol, E. R., Torrens, C. L., Jaros, C., et al. (2017). Characterizing hyporheic exchange processes using high-frequency electrical conductivity-discharge relationships on subhourly to interannual timescales. Water Resour. Res. 53, 4124-4141. doi: 10.1002/2016WR019739

Smedley, P. L., and Kinniburgh, D. G. (2002). A review of the source, behaviour and distribution of arsenic in natural waters. Appl. Geochem. 17, 517-568. doi: 10.1016/S0883-2927(02)00018-5

Smith, C. (2018). Interim Remedial Actions Bonita Peak Mining District Superfund. San Juan County, Colorado; Denver, CO: U.S. Environmental Protection Agency.

Stanton, M., Yager, D., Fey, D., and Wright, W. (2007). "Chapter E14: Formation and geochemical significance of iron bog deposits," in US Geological Survey Professional Paper 1651, vol. 2, eds S. E. Church, P. von Guerard and S. E. Finge (Reston, VA), 693-718.

Thompson, S. E., Basu, N. B., Lascurain, J., Aubeneau, A., and Rao, P. S. C. (2011). Relative dominance of hydrologic versus biogeochemical factors on solute export across impact gradients. Water Resour. Res. 47, 1-20. doi: 10.1029/2010WR009605

Trauth, N., Schmidt, C., Vieweg, M., Maier, U., and Fleckenstein, J. H. (2014). Hyporheic transport and biogeochemical reactions in pool-riffle systems under varying ambient groundwater flow conditions. J. Geophys. Res. Biogeosci. 119, 910-928. doi: 10.1002/2013JG002586

Trostle, K. D., Runyon, J. R., Pohlmann, M. A., Redfield, S. E., Pelletier, J., McIntosh, J., et al. (2016). Colloids and organic matter complexation control trace metal concentration-discharge relationships in Marshall Gulch stream waters. Water Resour. Res. 52, 7931-7944. doi: 10.1002/2016W.R. 019072

USDA (2020). SNOwpack TELemetry Network (SNOTEL). Nat. Resour. Conserv. Serv. Available online at: https://www.nrcs.usda.gov/wps/portal/nrcs/detail/co/ snow/?cid=nrcs144p2_063325 (accessed April 20, 2020).

USEPA (2010). Low stress (low flow) purging and sampling procedure for the collection of groundwater samples from monitoring wells. North Chelmsford, MA: US Environmental Protection Agency. 30.

USEPA (2016). One year after the Gold King Mine Incident: A Retrospective of EPA's Efforts to Restore and Protect Impacted Communities. U.S. Environmental Protection Agency. Available online at: https:/www.epa.gov/sites/production/ files/2016-08/documents/mstanislausgkmlyrreportwhole8-1-16.pdf

USEPA (2017). Sampling Activities Report: 2017 Sampling Events, Bonita Peak Mining District Site San Juan/La Plata Counties, Colorado Final. Denver, CO: U.S. Environmental Protection Agency.

USGS (2020). National Water Information System data available on the World Wide Web (USGS Water Data for the Nation). U.S. Geol. Surv. Available online at: https://waterdata.usgs.gov/co/nwis/uv/?site_no=09358550\&agency_ $c d=$ USGS (accessed April 4, 2020).

Vincent, K. R., Church, S. E., and Wirt, L. (2007). "Chapter E16: Geomorphology of cement creek and its relation to ferricrete deposits," in US Geological Survey Professional Paper 1651, Vol. 2, eds S. E. Church, P. von Guerard and S. E. Finger (Reston, VA), 747-772.

Wagner, B. J., and Harvey, J. W. (1997). Experimental design for estimating parameters of rate-limited mass transfer: analysis of stream tracer studies. Water Resour. Res. 33, 1731-1741. doi: 10.1029/97WR01067

Walton-Day, K., Paschke, S. S., Runkel, R. L., and Kimball, B. A. (2007). "Chapter E24: Using the OTIS solute-transport model to evaluate remediation scenarios in cement creek and the upper animas river," in US Geological Survey Professional Paper 1651, Vol. 2, eds S. E. Church, P. von Guerard and S. E. Finger (Reston, VA), 979-1028. 
Weber, F. A., Hofacker, A. F., Voegelin, A., and Kretzschmar, R. (2010). Temperature dependence and coupling of iron and arsenic reduction and release during flooding of a contaminated soil. Environ. Sci. Technol. 44, 116-122. doi: 10.1021/es902100h

Wirt, L., Vincent, K. R., Verplanck, P. L., Yager, D. B., Church, S. E., and Fey, D. L. (2007). "Chapter E17: Geochemical and hydrologic processes controlling formation of ferricrete, in US Geological Survey Professional Paper 1651, Vol. 2, eds S. E. Church, P. von Guerard and S. E. Finger.

Wondzell, S. M. (2006). Effect of morphology and discharge on hyporheic exchange flows in two small streams in the cascade mountains of Oregon, USA. Hydrol. Process. 20, 267-287. doi: 10.1002/hyp.5902

Yager, D. B., and Bove, D. J. (2007). "Chapter E1: Geologic framework," in US Geological Survey Professional Paper 1651, Vol. 2, eds S. E. Church, P. von Guerard and S. E. Finger (Reston, VA), 111-137.

Zarnetske, J. P., Haggerty, R., Wondzell, S. M., Bokil, V. A., and GonzálezPinzón, R. (2012). Coupled transport and reaction kinetics control the nitrate source-sink function of hyporheic zones. Water Resour. Res. 48, 1-15. doi: 10.1029/2012WR011894

Conflict of Interest: RC was employed by company Alpine Water Resources, LLC.

The remaining authors declare that the research was conducted in the absence of any commercial or financial relationships that could be construed as a potential conflict of interest.

Copyright $\odot 2020$ Hoagland, Navarre-Sitchler, Cowie and Singha. This is an openaccess article distributed under the terms of the Creative Commons Attribution License (CC BY). The use, distribution or reproduction in other forums is permitted, provided the original author(s) and the copyright owner(s) are credited and that the original publication in this journal is cited, in accordance with accepted academic practice. No use, distribution or reproduction is permitted which does not comply with these terms. 